\title{
Landscape experiments along the Italy, Austria and Slovenia border
}

\begin{abstract}
The research started from focusing on a border line that runs for $180 \mathrm{~km}$ along the edge of 3 States, 5regions, numerous landsca-pes. Eventually, putting together the eleven visions elaborated by the working groups, an extended area of about $7000 \mathrm{~km}^{2}$ was identified as the actual "region of the border". This regions lays within a bigger cross-border ring whose shape is defined by pieces of existing infrastructures, belonging to other systems, but representing, within the ring around the border, a "new" important infrastructure serving the territory. It also represents a functional unity, a perception system, in few words a whole structural unity for the region of the border.
\end{abstract}

Keywords: landscape, Italy, Austria, Slovenia border, geography, rhythm and fluxes, region, ecologies
Volume 3 Issue 5 - 2019

\section{Adriano Venudo \\ Department of Engineering and Architecture, University of Trieste University Center of Gorizia, Italy}

Correspondence: Adriano Venudo, Department of Engineering and Architecture, University of Trieste University Center of Gorizia, via Bartolomeo D'Alviano 18, 34I 70 - Gorizia, Italy, Tel 048I 599236 \& 347 2921588, Email avenudo@units.it

Received: September 13, 2019 | Published: October 01, 2019

\section{Introduction}

\section{Landscapes on a moving border}

Apparently still, geography does instead re-write and inform always new architectonic languages; vice versa architectureif considered from the geographer's point of view., ${ }^{1,2} \mathrm{Re}$-shapes periodically, through scales, history of geography and its very representation, always new relations, arrangements, original texts that are the result of territorial processes. That is, in Corboz's ${ }^{3}$ words, the codification of the palimpsest. This article summarises the findings of a research conducted by the author in collaboration with the Univeristy of Trieste's and Faculty of Architecture of Lubljana's workshop "Progettazione Integrata dell'Architettura e del Costruito". The research focused on the change ongoing along the Italian, Austrian and Slovenian border in north-eastern Italy, following the geo-political developments of the last 20 years Figure 1.

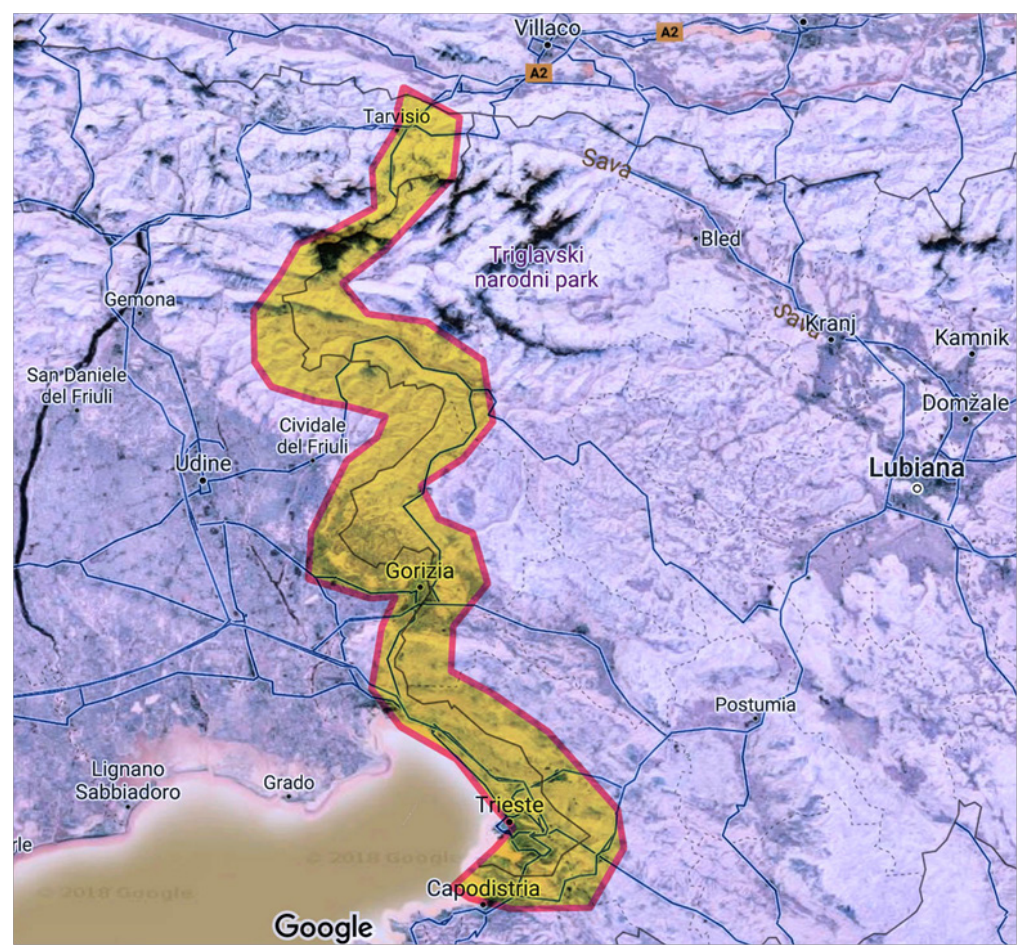

Figure I extension of the border $(180 \mathrm{~km})$ among Italia, Slovenia, Austria. 
The research had 3 main objectives: 1. Elaborating a new interpretation of architecture and landscapes, shaped on the geographic matrix of the border, in the aforementioned cross-border region; 2. Developing a cross-cutting dialogue on territorial models shaped on the edge between geography and architecture; 3 . Designing landscape and urbanistic project proposals for cross border areas within a cross border cooperation mindset. The research area is set along the Italian, Slovenian and Austrian border of Friuli Venezia Giulia region, in north- eastern Italy, from the mountains of Tarvisio to the Adriatic sea shore. The actual border runs for a $180 \mathrm{~km}$ around 3 sides of the perimeter of the region, but an extended area of $7000 \mathrm{~km}^{2}$ have been also included in the study site. This extended area represents a landscape unit, stratified with history and traditions of the communities that inhabit it (rhythm and fluxes), and represents a territory with a unique potential for the development of new projects Figure 2.

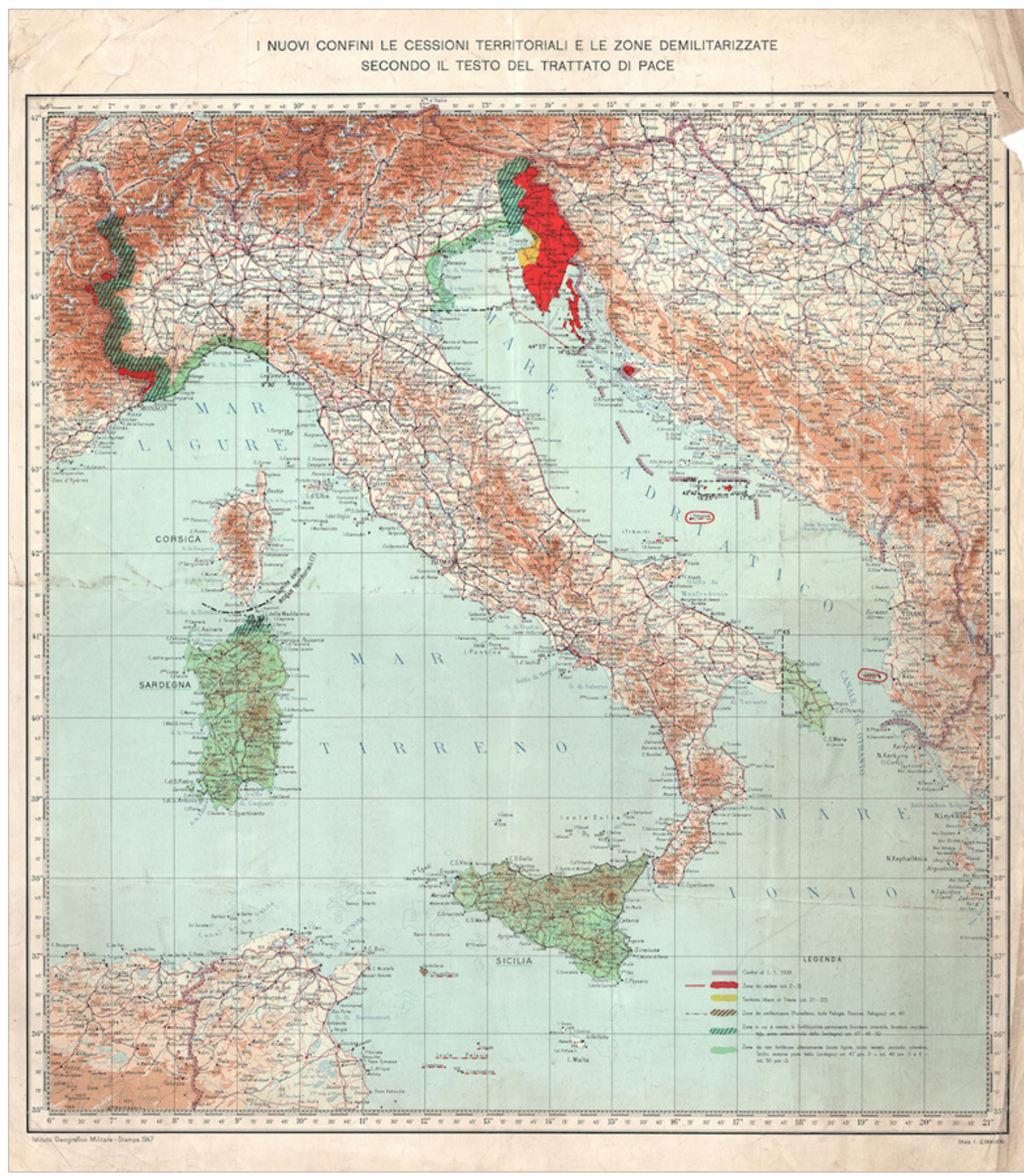

Figure 2 Military Geographic Institute, Official Map of the Italian State before the Peace of Paris, 1947; Source: www. italianlimes.net. 
The border at stake, for known historical reasons ${ }^{4}$ and, more recently, due to geo-morphological changes (i.e. it runs along the alpine region, where high altitude glaciers are currently shrinking due to climate change and fastly re-shaping the morphology of the land), is defined as a "moving" border. The alpine area moves along the movement of the glaciers, and so does the border, thus yearly modifying, even so slightly, the official geo-political maps Figure $3 \& 4 .^{5}$ To address this issue, the States along the Alpine chain (including Austria, Slovenia and Italy) have thus officially codified the concept of "moving border" and that of "instability of geological elements", traditionally considered unchanging. This leads to the scientific acknowledgement of the instability of natural borders, one of the pillars at the base of the concept of national territory Figure 5. Will climate change reshape, beside landscape structure, also the identity of these areas? ${ }^{6}$

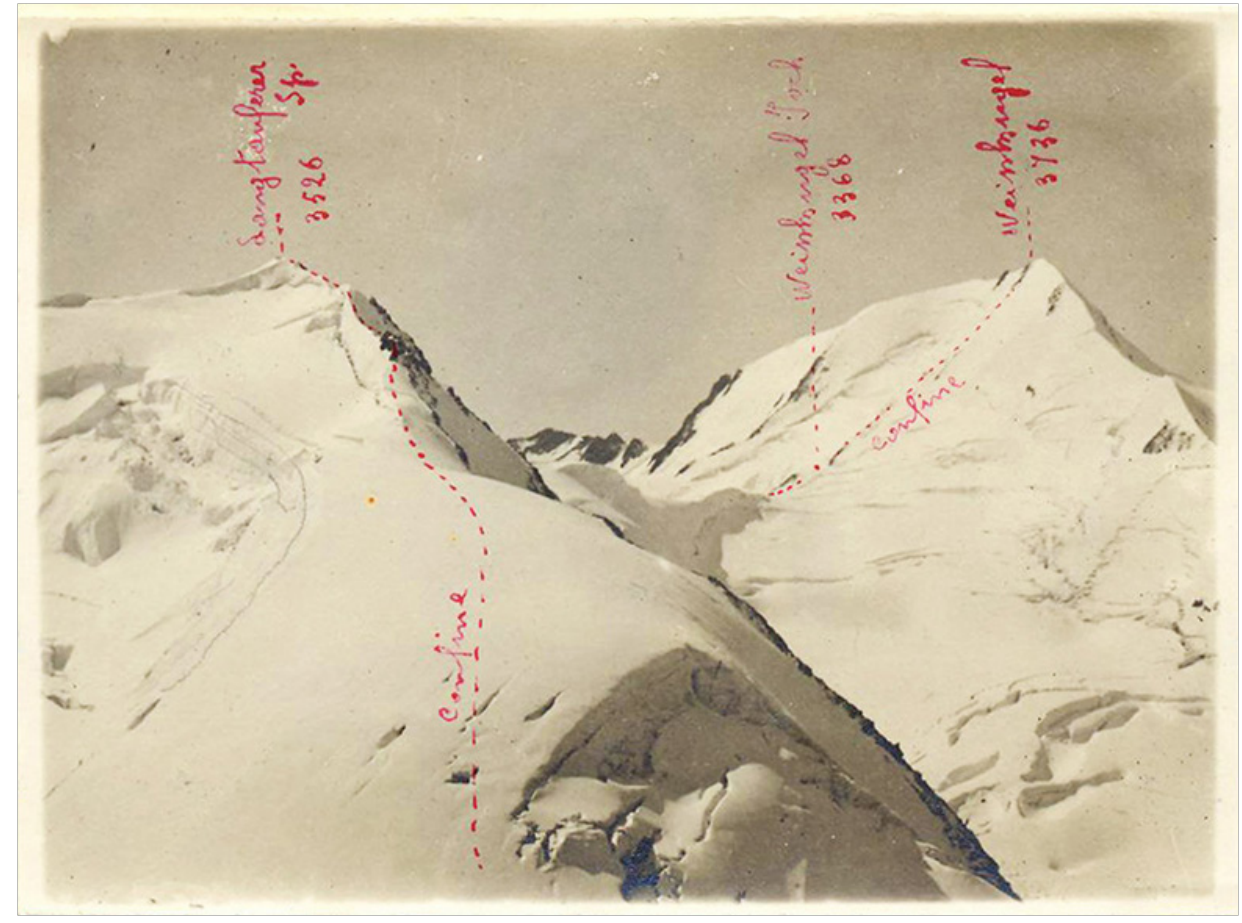

Figure 3 Military Geographical Institute, glaciers on the Italy-Austria border, 1929; Source: www.italianlimes.net.

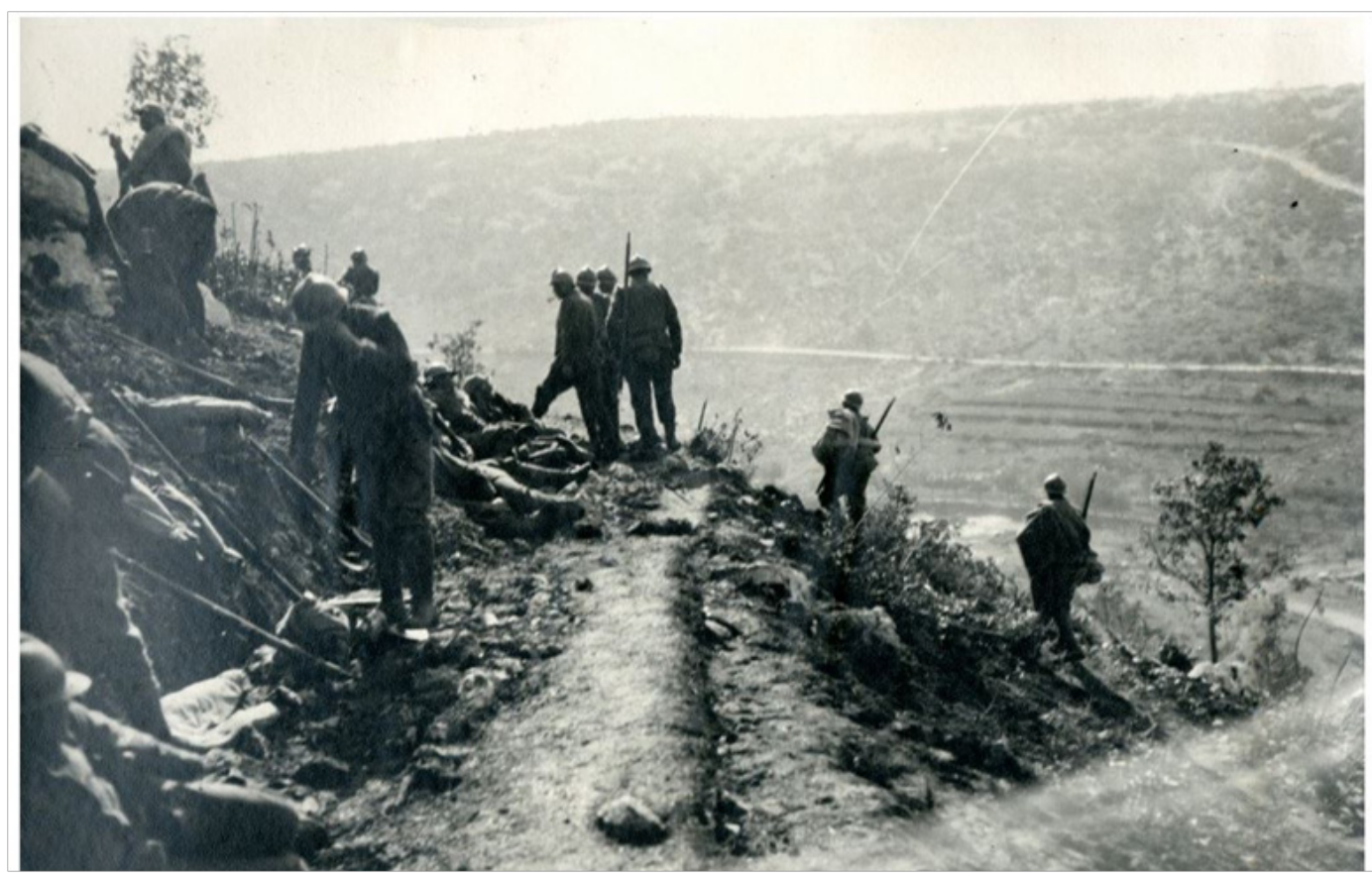

Figure 4 Images of the trenches in Doberdò del Lago, the Carso Goriziano, during the First World War, 1916. 


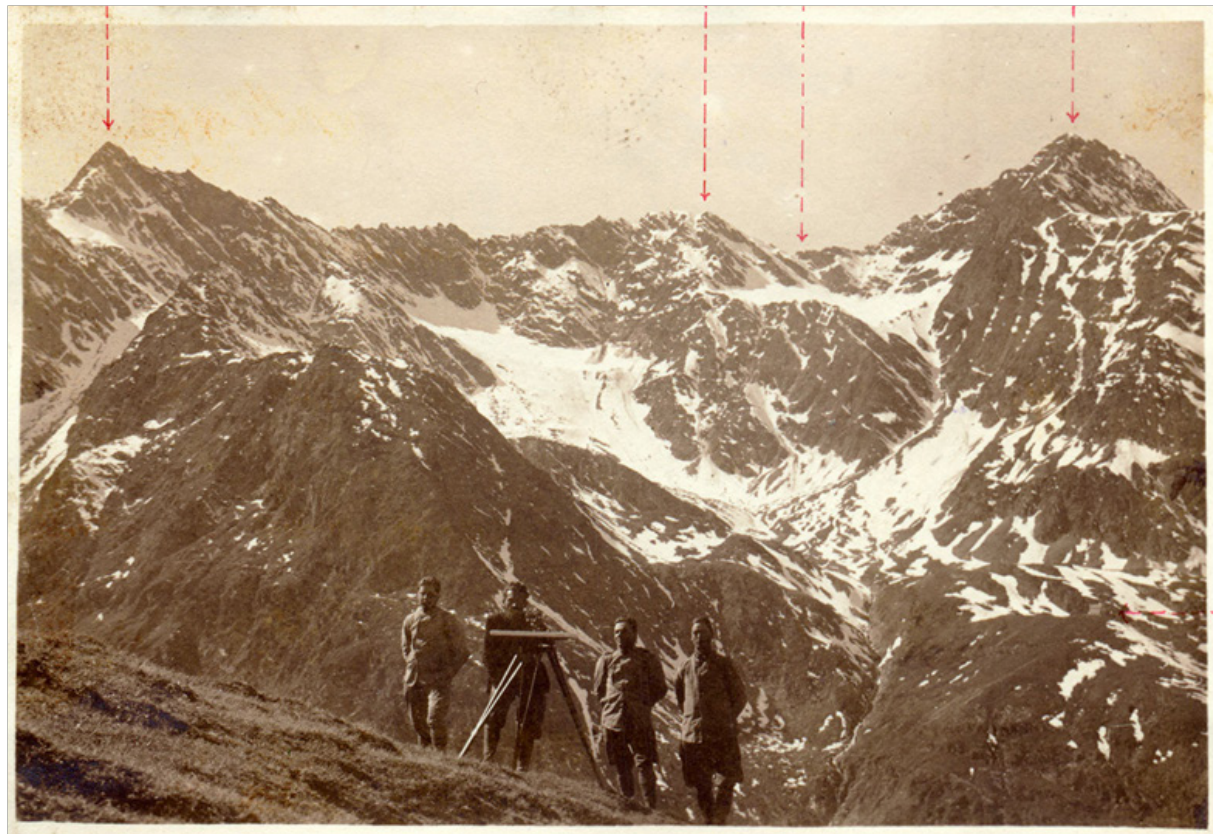

Figure 5 Geographers who measure the border between Italy and Austria, 1920.

The research was conducted in 4 phases, through survey and project tools, words and media for geographic elaboration, looking for the subtle connection between word and content, mapping and structure, territory and environment, landscape and place, shape and image Figure 6. Eleven working groups were created to work each on one of the identified themes. The work of each group was put together with that of the others to shape the new landscape's mosaic. Eleven visions were developed, each imagining a new geography of the border. Together, they acrobatically re-designed a new morphology of the limes, palimpsest of a multiethnic community where the remains of the history of places can write a new story between geography, landscape and architecture. These eleven visions in turn become the project making material for the overall re-shaping of landscape. The concept of "border as landscape" becomes then a key to identify the geographies of this cross border region. The geographer Giorgio Valussi, between the end of 1950s and mid 1960s, conducted a series of studies on Carsic landscapes, both in Italy and Slovenia, leading him to formulate the theory of the "geography of the border", finding its roots in the continuous changes within landscapes Figure $7 \& 8$. $^{7}$

\section{Discussion Ecologies of change}

At the roots of the proposal for this "new geography of the border" lays an original research on the structure of territory (systems and functioning), on landscape layering and on an attempt to measure change (physical, ethnic, social, economic, etc.), considered as a structural element of the "moving border". In order to map the ecologies of communities, ${ }^{8}$ eleven characters were chosen to represent the layering of the territory and of its landscapes, and their perspectives were used for mapping changes, as key indicators of the complex ongoing transformations.

These characters are:

I. Inhabitant;

II. The poet;
III. The onlooker;

IV. The artist;

V. The commuter;

VI. The unemployed;

VII. The priest;

VIII. the collector;

IX. The miner;

$\mathrm{X}$. The traveler;

XI. The pilgrim.

The representation of the ecologies of change ${ }^{9}$ is embodied in eleven cartographies that together show the moving dimension of the border space. These are:
i. Map of resonance;
ii. Map of poetic actions;
iii. Map of landscapes;
iv. Map of intersections;
v. Map of the arcipelago;
vi. Map of stratigraphy;
vii. Map of memories;
viii. Map of paths;
ix. 9 Map of diagenesis;
x. Map of fluxes;
xi. Map of exceptions in Figure 9. 
This constant change of the territory, that could apparently seem an issue for territorial identity, represents indeed an element of unity (physical, morphologic, economic, ethnic, of landscape and territory, etc.) and the main character of the identity of the cross-border region. ${ }^{10}$ This is indeed the reason behind the attempt to elaborate a "new own geography", based on the paradigm of mutation itself Figure 10-13. ${ }^{11}$

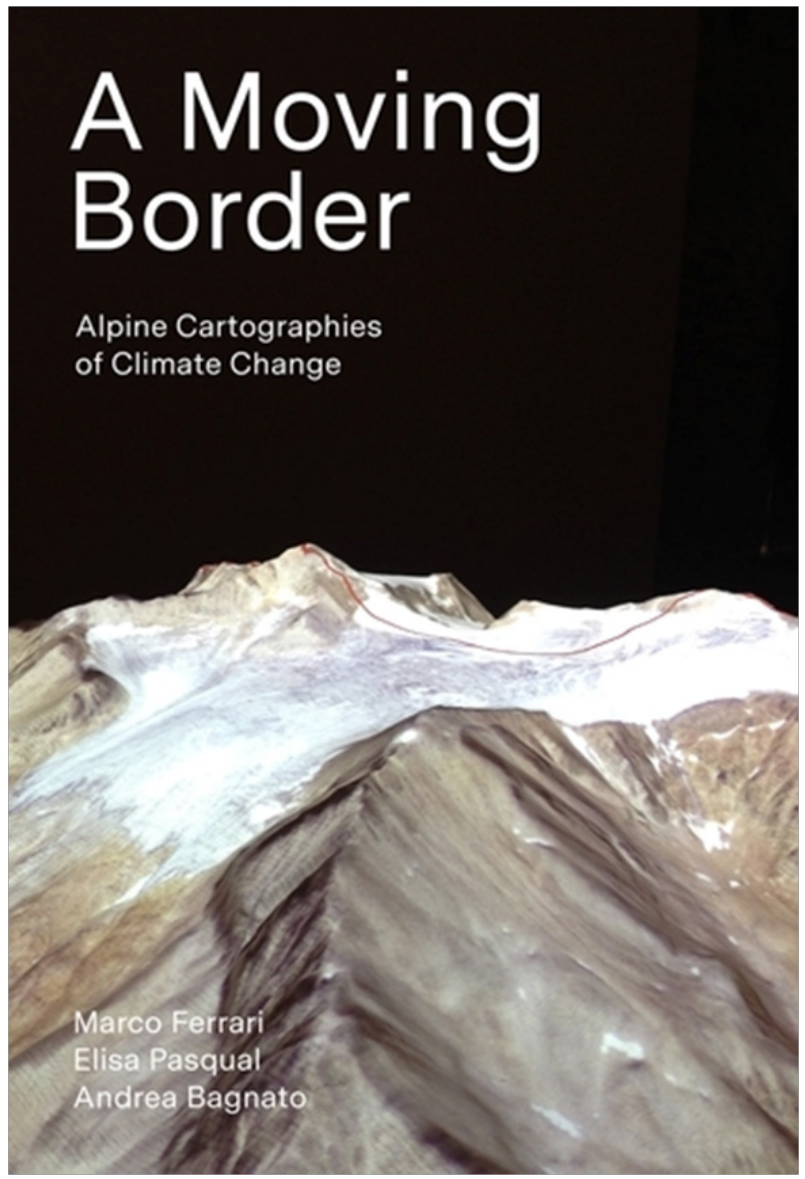

Figure 6 Book cover "A Moving Border" di M Ferrari, E Pasqual, A Bagnato, 2018.

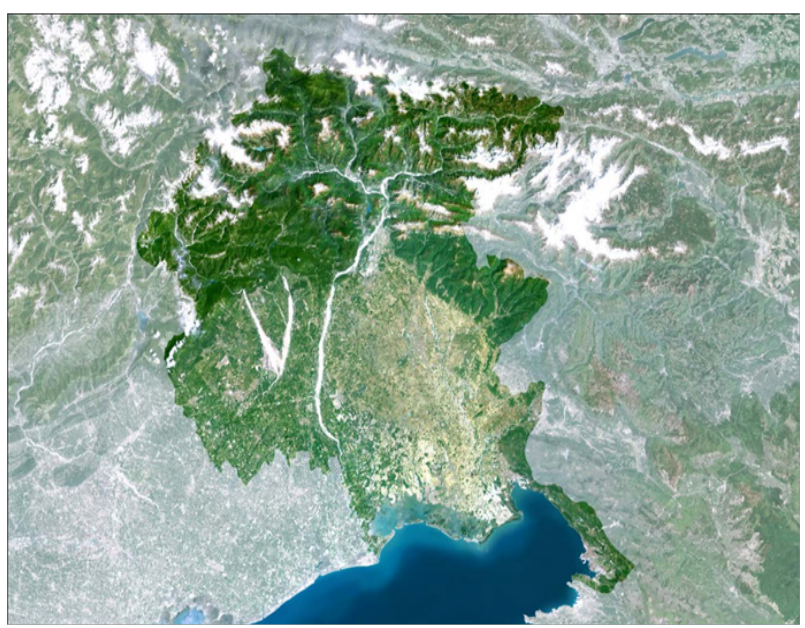

Figure 7 Regions of the Italy, Slovenia, Austria border: Friuli Venezia Giulia, Carinzia, Goriška, Gorenjsk e Obalno Kraska.

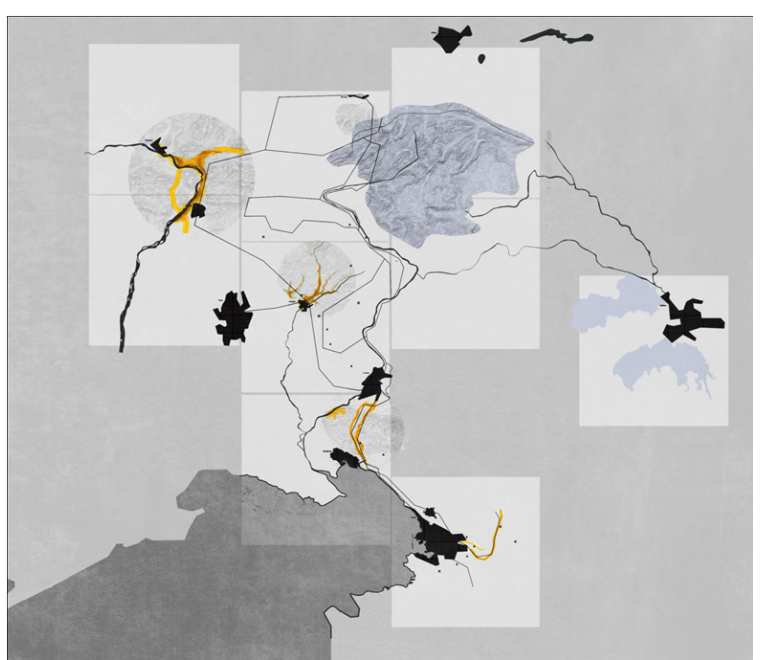

Figure 8 Elaboration of the research group of the Cross-border Region along the border. Students Kratter Lorenzo; Lesizza Giada; Bertoni Angela.
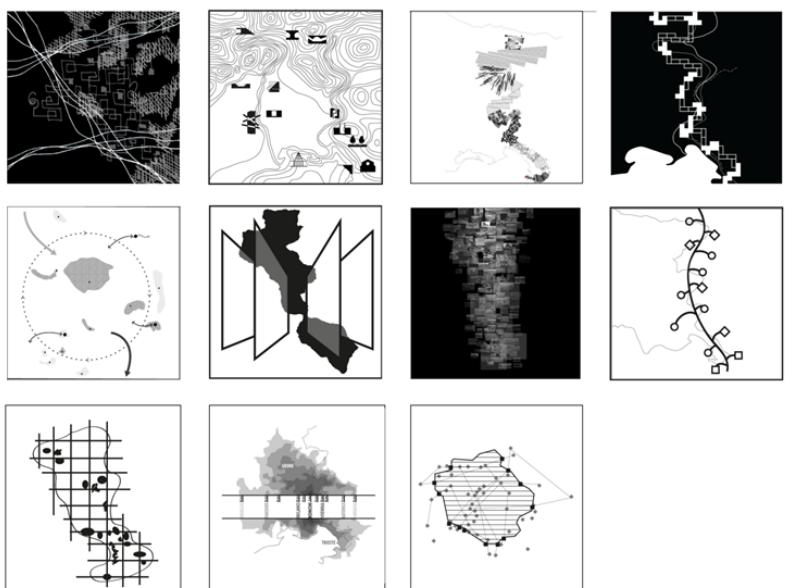

Figure 9 Elaboration of the research team (see final list of students LPI AC 2018- 2019). Map of the ecologies of change.
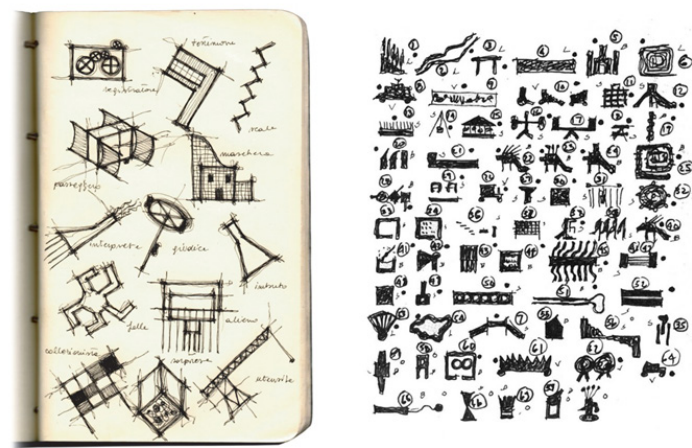

constellations

victims

Figure I0 Elaboration of the research team (see final list of students LPI_AC 2018-2019). Map of the ecologies of change. 


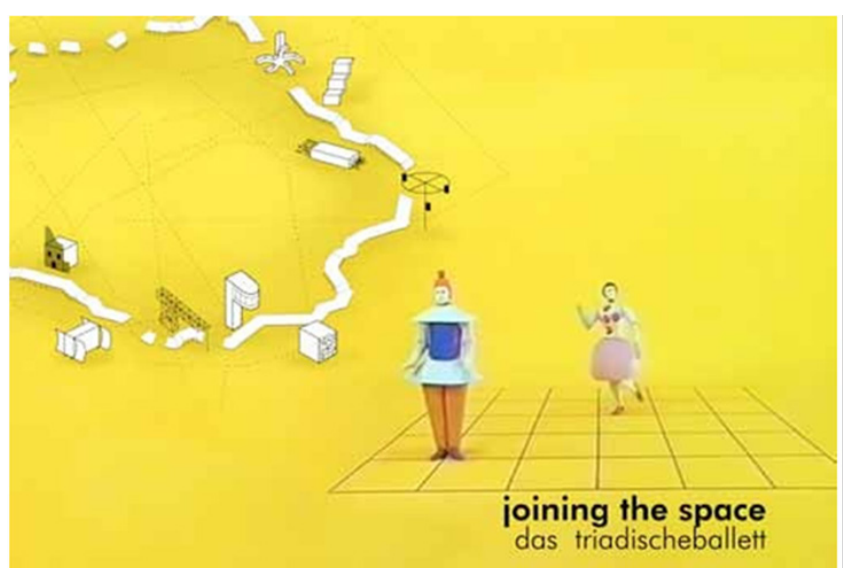

Figure I I Elaboration of the research team (see final list of students LPI_AC 2018- 2019). Map of the ecologies of change.

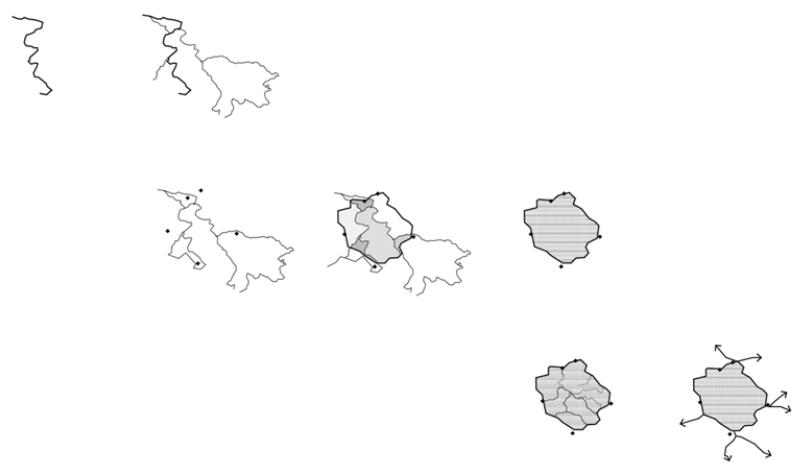

$180 \mathrm{~km}$ in $7000 \mathrm{~km}^{2}$ from the line to the surface

Figure I 2 Development of the research team, students Matteo Savron, Elwira Wojcicka, Monica Bidoli. From the territory along the border to the region of the trans-border ring around the border.

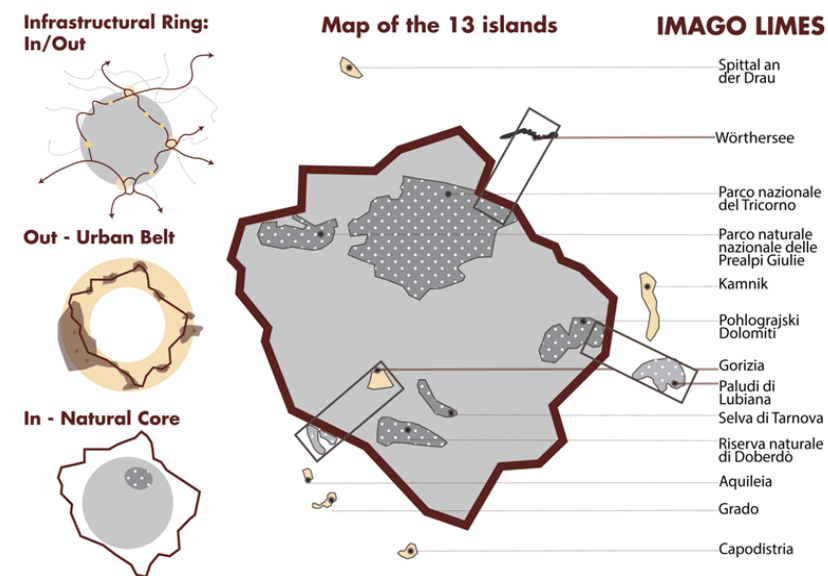

Figure I 3 Development of the research team, students Matteo Savron, Elwira Wojcicka, Monica Bidoli. Analysis of the internal systems and of the operation of the cross- border ring around the border.

\section{Hypothesis}

\section{The ring for landscape border as a pre-geography?}

The research started from focusing on a border line that runs for $180 \mathrm{~km}$ along the edge of 3States, 5regions, numerous landscapes. Eventually, putting together the eleven visions elaborated by the working groups, an extended area of about $7000 \mathrm{~km}^{2}$ was identified as the actual "region of the border". This regions lays within a bigger cross-border ring whose shape is defined by pieces of existing infrastructures, belonging to other systems, but representing, within the ring around the border, a "new" important infrastructure serving the territory. It also represents a functional unity, a perception system, in few words a whole structural unity for the region of the border. The infrastructures taken into account for this new re-shaping of the functionalities of the territory are highways A4 and A23 in Italy,E61 and E652 in Slovenia and A2 in Austria. Re-interpreting the territory according to this ring structure, an original constellation oflandscapes, natural systems, small centres, linear settlements and cities appears to the view and, with due care related to the still existing local and national fragmentations, they could be considered together as a whole, huge "border city" Figure 14

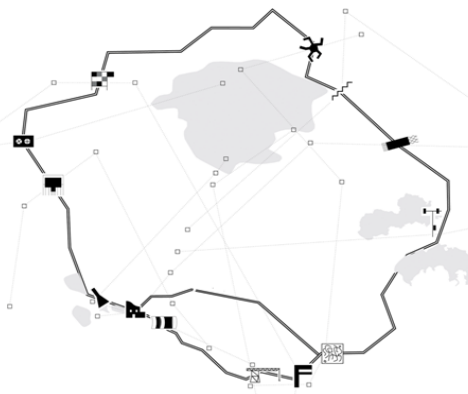

Figure 14 Development of the research team, students Matteo Savron, Elwira Wojcicka, Monica Bidoli.The cross-border ring.

Starting from the shape of the cross-border ring, different themes were investigated Figure 15-17:

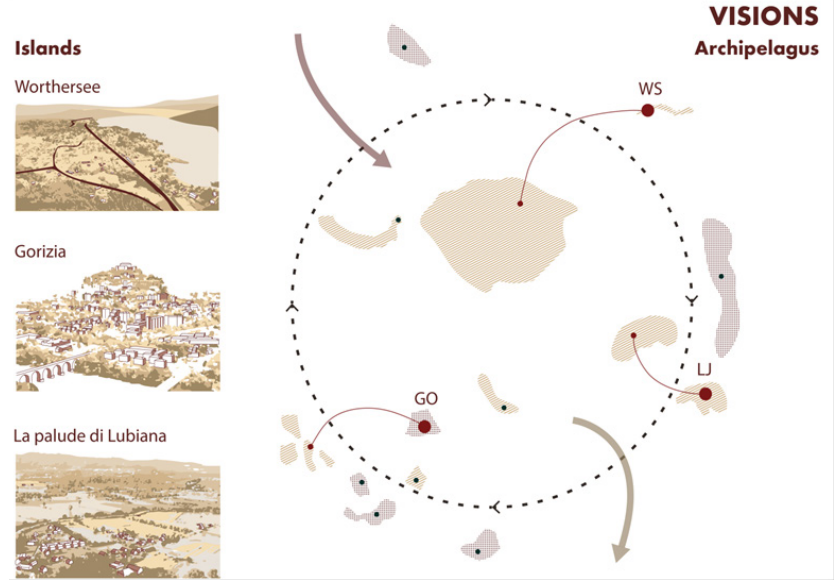

Figure 15 Development of the research team, students Matteo Savron, Elwira Wojcicka, Monica Bidoli.Analysis of the landscapes of the transboundary ring around the border. 


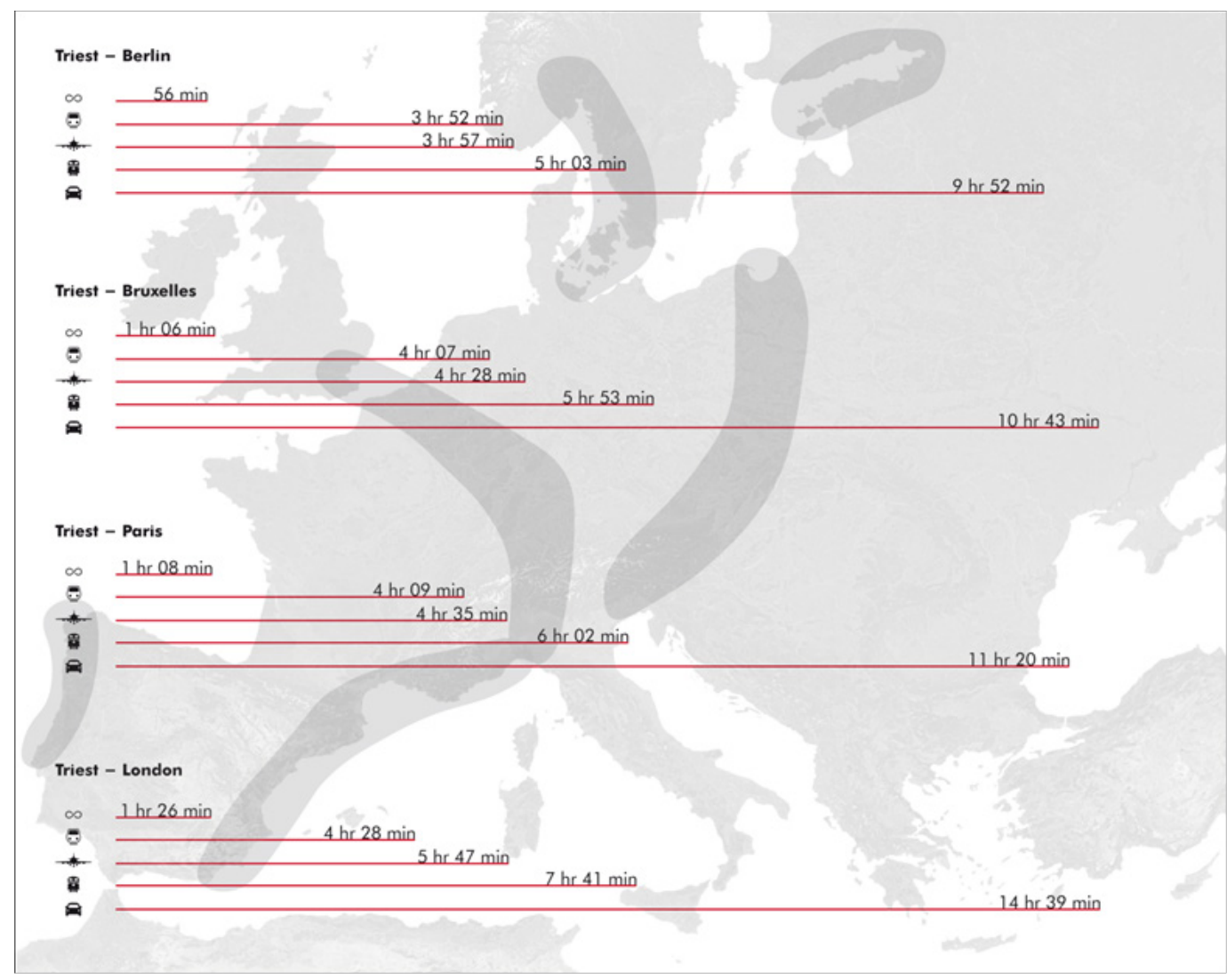

Figure 16 Development of the research team, students Matteo Ros, Milisa Stankovic, Enrico Vidulich.Timtable della regione transfrontaliera comparata con le principali mete europee. We are already contemplating the scenario of the hyperloop presented at the Architecture Biennale of Venice 2018.

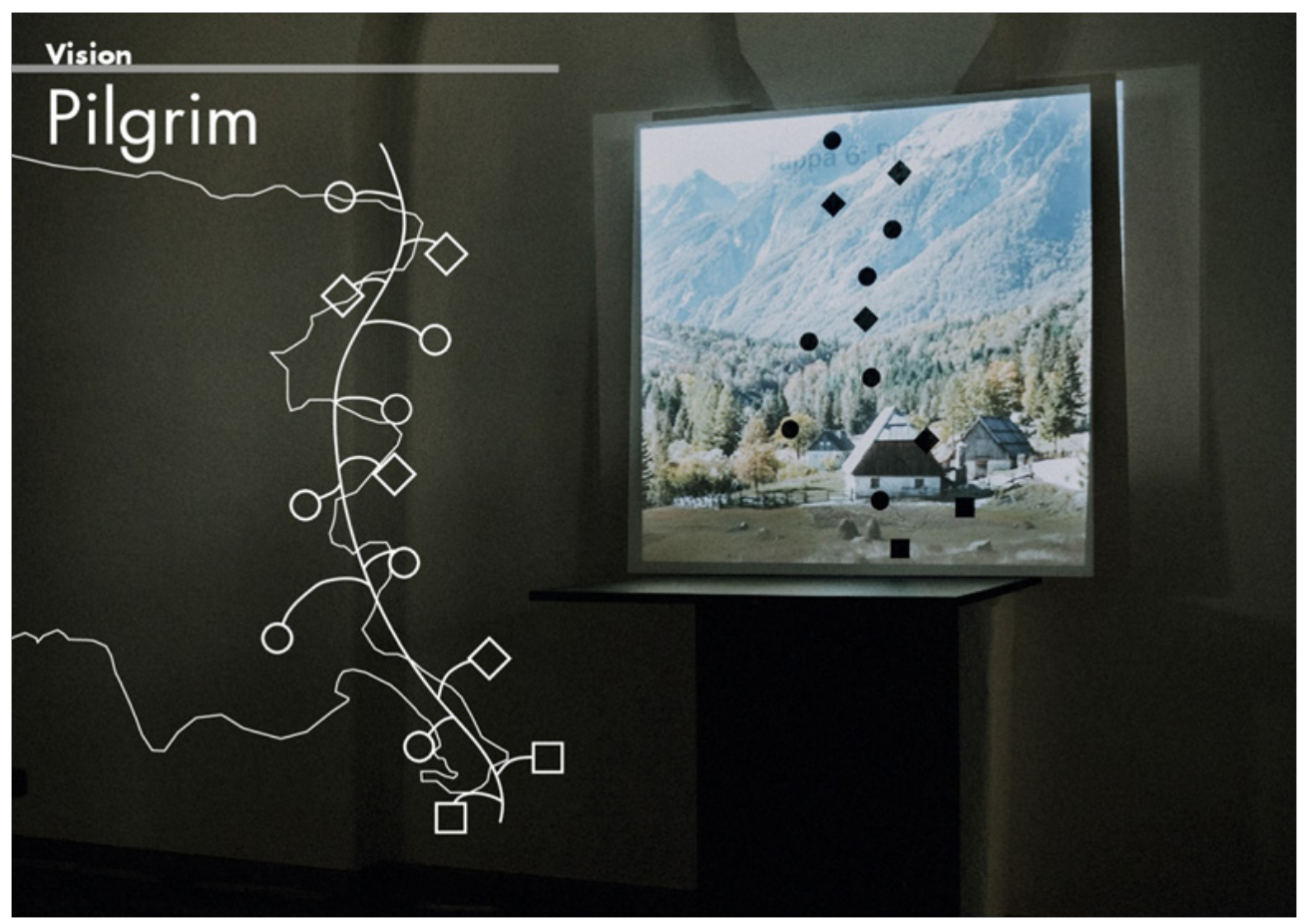

Figure 17 Development of the research team, students Caporale Giacomo. Connessioni Lente. Nuovi itinerari spirituali e di pellegrinaggio lungo il confine. 
i. Dimension, perception, stratifications;

ii. Re-reading, narrations and landscapes, literature and poetry of the territory;

Landscape unity, natural macrosystems, environment, vegetational structures, panoramic views;

i. Art and nature;

ii. Systems, infrastructures, territorial settlements, heritage system;

iii. Abandonment;

iv. Memory and territorial symbology;

v. Backbone and infrastructure;

vi. Morphology, lithology and extraction plants;

vii. European corridors and regional networks;

viii. Slow landscapes, paths, places of worship;

The analytical reading was elaborated with 2 visions in mind:

I. A taxonomy chart of landscapes (sound, imagination, perception, art, mankind, habits, industrial archeology, memory, movement, earth, speed, spirituality);

II. A new "map" allowing for a new interpretation of the border extended area as a whole territory, with its own geography.

The eleven visions elaborated (thematisms) codify the layers of the cross-border landscape, with the aim to develop:

I. Tools allowing for the interpretation of the ongoing change;

II. A "pre-geography of the border", aimed at orienting the urban and landscape planning within the cross border cooperation framework among Italy, Slovenia and Austria.

\section{Mapping and framework of the existing fragmentation} and unity of a cross border region

The study area runs across the border regions of Friuli Venezia Giulia in Italy, Carinthia in Austria and Goriška, Gorenjsk and Obalno Kraska in Slovenia. This area has, throughout history, always been a passage towards the East. The territory has always been divided among different national States, but can be considered as a whole for what concerns its "common matrix", rooted in its identity of a cross border region. ${ }^{12}$ In the last two centuries the region was subject to great transformations, from the administrative and political point of view. These changes have left their traces on the physical appearance of the territory as well as on the communities that inhabit it. Multiethnicity has always represented the base for the mixing of cultures and local identities. The main reason behind the dynamic balance between unity and fragmentation within this region is the high level of permeability of this border, defined also as an "open border" ${ }^{13}$ The paradigm of change lives within the very genetic heritage of this territory, both from the physical/morphologic and from the anthropological/cultural perspectives. Currently three national States (Italy, Slovenia and Austria) share this border, but the region itself is a whole macro-region, unified by history, culture and geo-morphology. Territorial systems overlap and shape different geographies, thus filling in the space of the border according to the "cross-border concept"14 or to the idea of "transational cell" Figure 18. ${ }^{15}$ The natural systems of the territory at stake (Sistema Carta Natura,ISPRA) have a strong ecological and landscape unity (woods and forests, rivers, lakes, mountain ranges, glaciers, valleys, coast). The many small towns and five bigger centers (Tarvisio, Gorizia, Trieste, Lubljiana, Villach) located in this area, for historical reasons (such as re-definition of the borders between States after the II World War) found themselves without a real territory beside the fragmented one represented by the cross border. The geographic position as gate towards the East has favored, throughout the centuries, the creation of important transport infrastructures and of the European corridors. This allowed for a direct connection with central Europe, for what concerns trade and commerce. Thus, this "informal region", geographically located in a peripheral position, was included in a continental exchange loop, despite not being officially recognized as a whole unit from the political, administrative and economic point of view. It seems thus relevant to point out that the fragmentation and constant change that the border has always generated in this area has paradoxically given birth to a unitary territorial entity, that was also partially formalized, in the last 25-30years, as Euroregion, Alpe Adria, Macroregion, etc., for economic, political administrative, environmental, managerial, social, landscape purposes Figure 19-22.

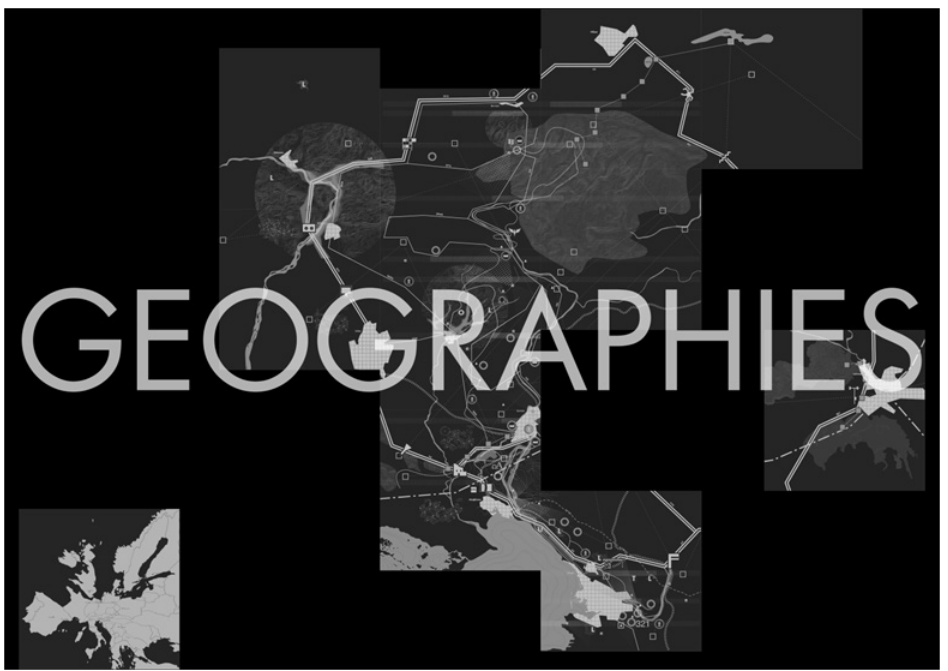

Figure 18 Development of the research team, (vedi elenco finale studenti LPI_AC 2018- 2019). New geography of the border region. 


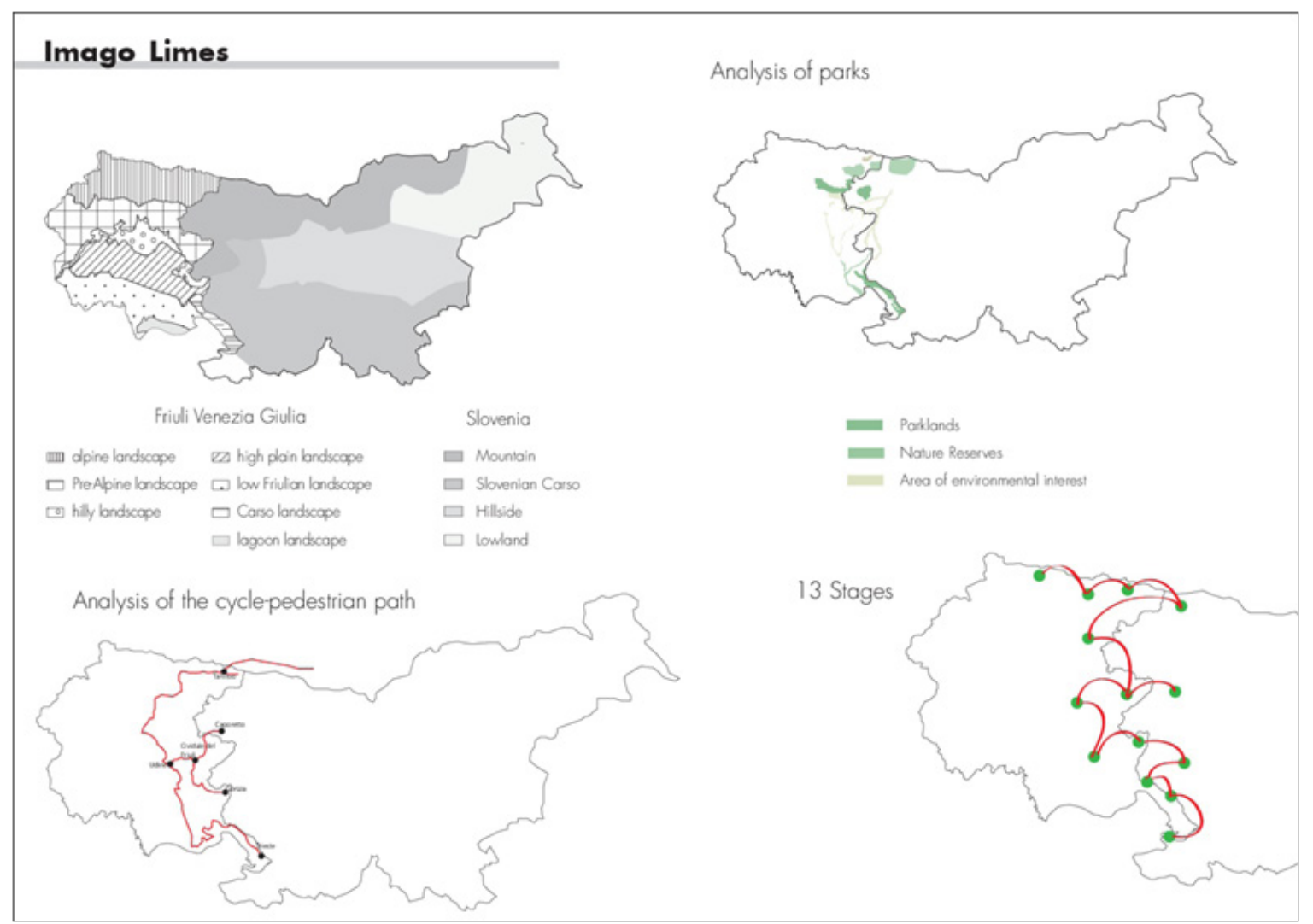

Figure 19 Development of the research team, students Caporale Giacomoi. Analisi dei paesaggi, dei percorsi lenti, delle emergenze, dei luoghi di culto lungo il confine.

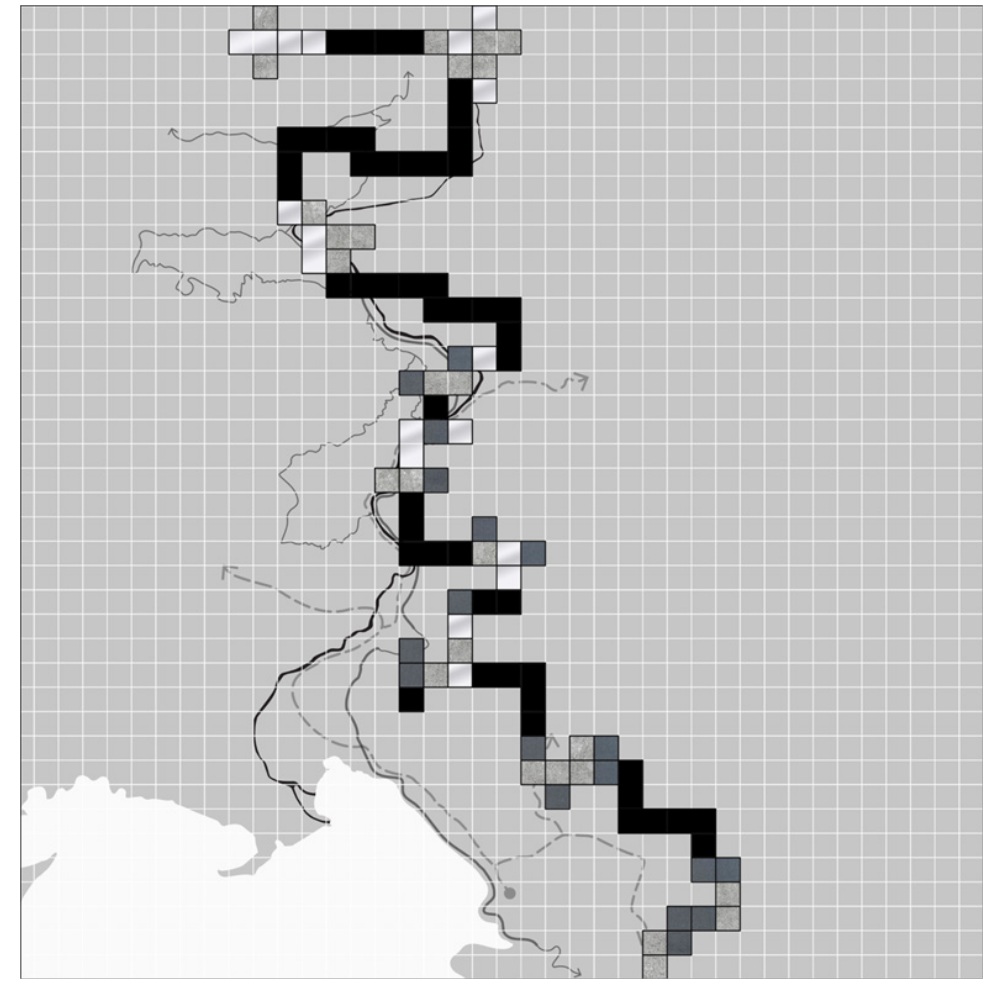

Figure 20 Development of the research team, students Sofia Artico, Federica ferrigno, Lara Slavec.Analysis of environmental systems and scheme of ecological fragmentation along the border. 


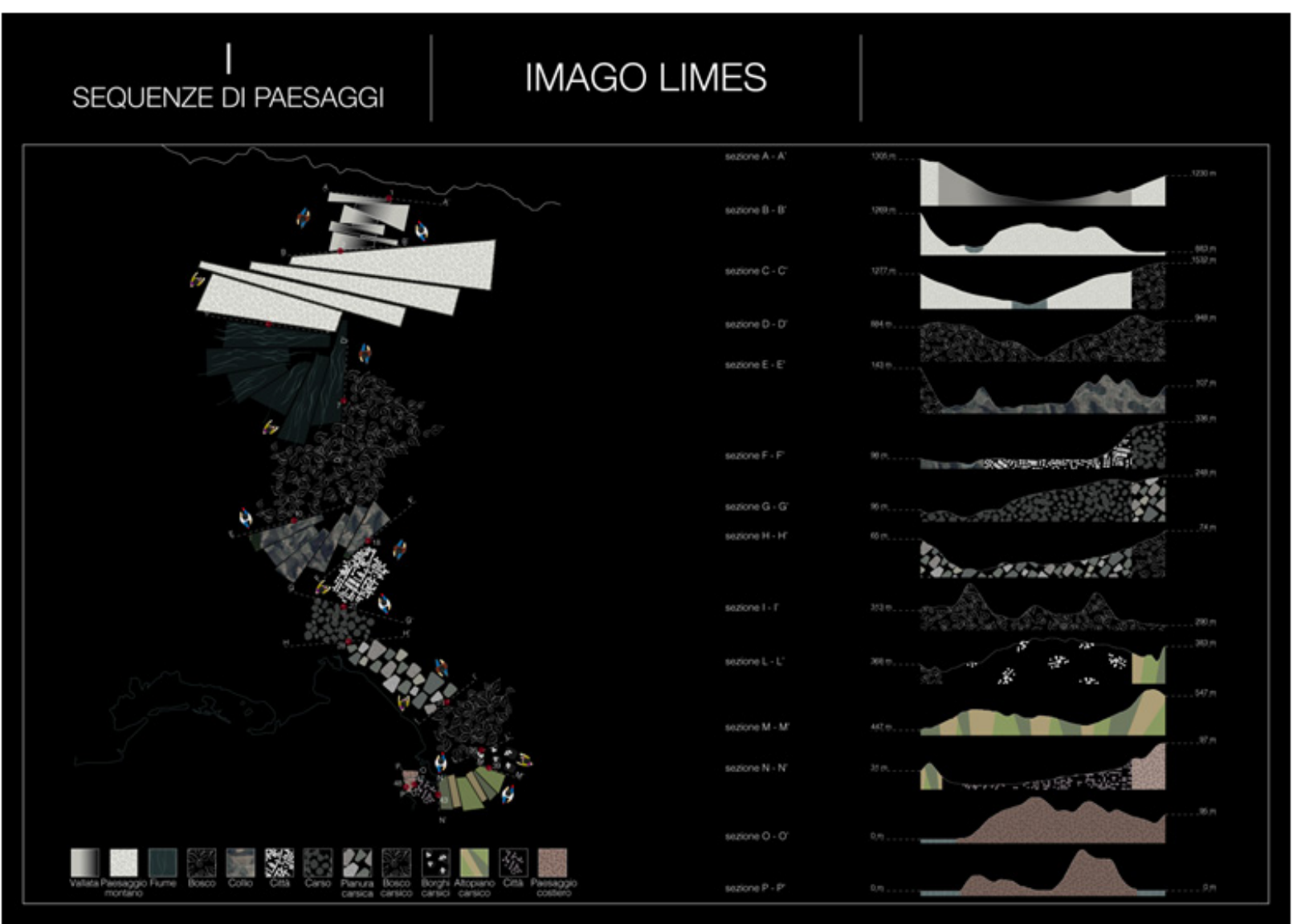

Figure 2I Development of the research team, students Giorgio Conforto, Eleonora di Stefano, Debora Paulin.Analysis of landscapes, sequences and perceptions along the border in relation to cross-border crossings.

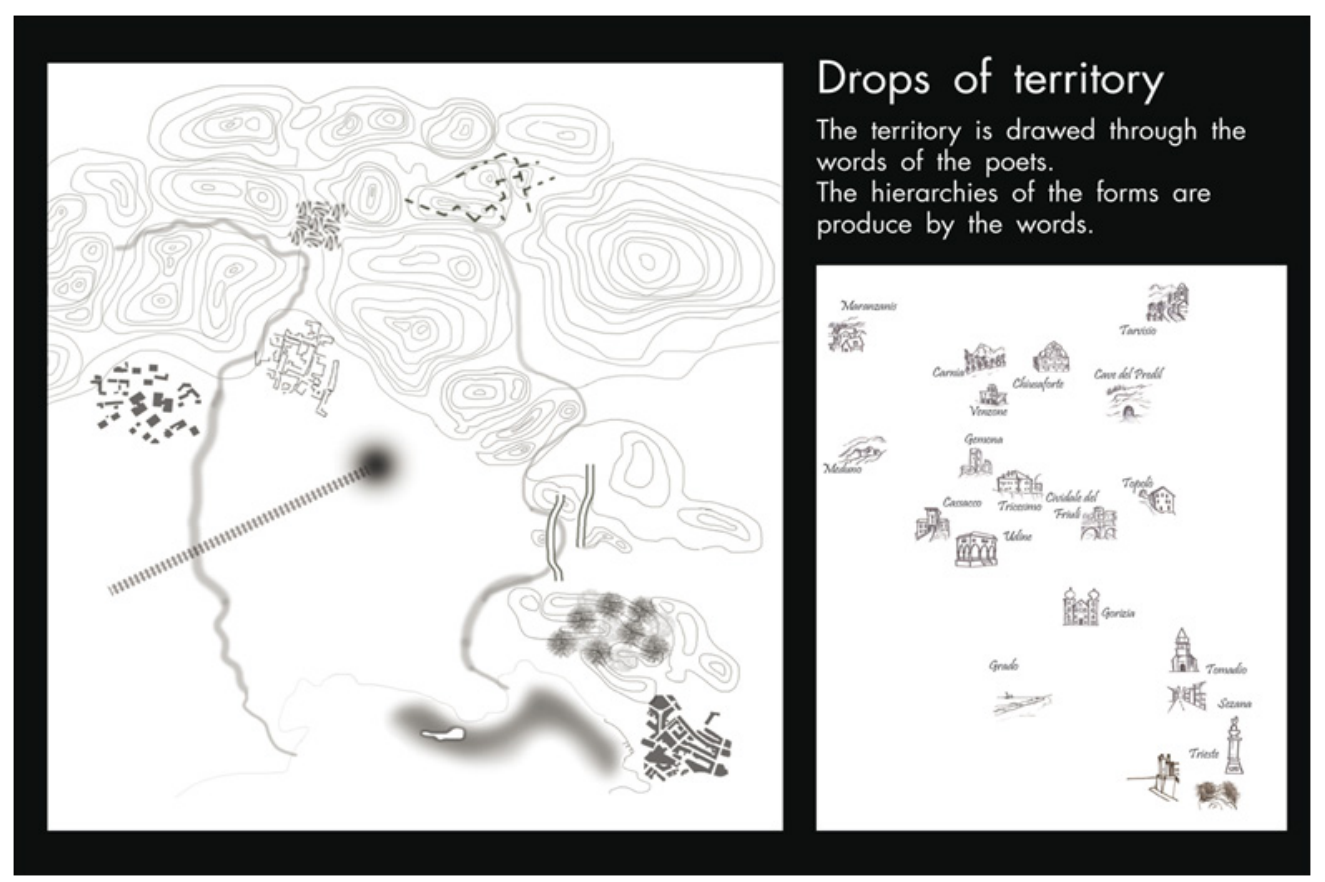

Figure 22 Virginia Fabbro, Silvia Musini, Arianna Santarsiero. Mapping of landscape, "poetic mapping. 


\section{Conclusions and results}

\section{From landscape architecture to shapes of geography}

The project-making approach towards the elaboration of a masterplan aimed at valorizing the diversities within the territory, that have always shaped the ways of life and of inhabiting, ${ }^{16}$ the settling principles at the roots of cross border cities and villages, the ways of cultivating and managing landscape, the creation of an architectonic jargon of the border. ${ }^{17}$ The masterplan investigates forms and "shapes of diversity" that are capable of enhancing unity and sense of belonging to a whole territory. The history of the city and of the territory ${ }^{1}$ remind us that great infrastructures, such as the roman aqueducts, the consular roads, the defensive structures of the Chinese Great Wall or Adrian's Wall, the pilgrimage routes, and more recently the European corridors have always contributed to shaping unity (Figure 23-28). However, history suggests also other means for building unity, ${ }^{2}$ for instance through the dedicated, symbolic or functional construction of bell towers, or landmarks, water tower telemetry, or the development of a "unitary vision" through great landscape and perspective rearrangements, theorized by Benevolo ${ }^{2}$ in "Cattura dell'Infinito". The shaping of the territory, especially in the Mittel-European area, has been understood and developed as management of change ${ }^{13}$ and historically was always embodied by landscape architecture, ${ }^{2}$ while finding its actual effectiveness (both in terms of realization and dissemination) only when codified by geography. ${ }^{9}$ Important examples to illustrate this connection throughout history are the Peuntiger Table, or the first cartographies of the territory of the Venetian Republics by Guadagnino, or the great topographic campaigns of the Austro-Hungarian Empire or of the Italian Geographic Military Institute. Also maps and tourist guides elaborated by the Italian Touring Club highly contributed to the creation of a culture and awareness of landscapes (Figure 29-31). Finally, it is worth also mentioning as an example the recent maps of the "future world order", related to communication, new media and energy. ${ }^{18}$ A constant evolution of forms of the geographical space has taken place parallel to human evolution, and to the evolution of tools and methods (Figure 32\&33). ${ }^{19}$

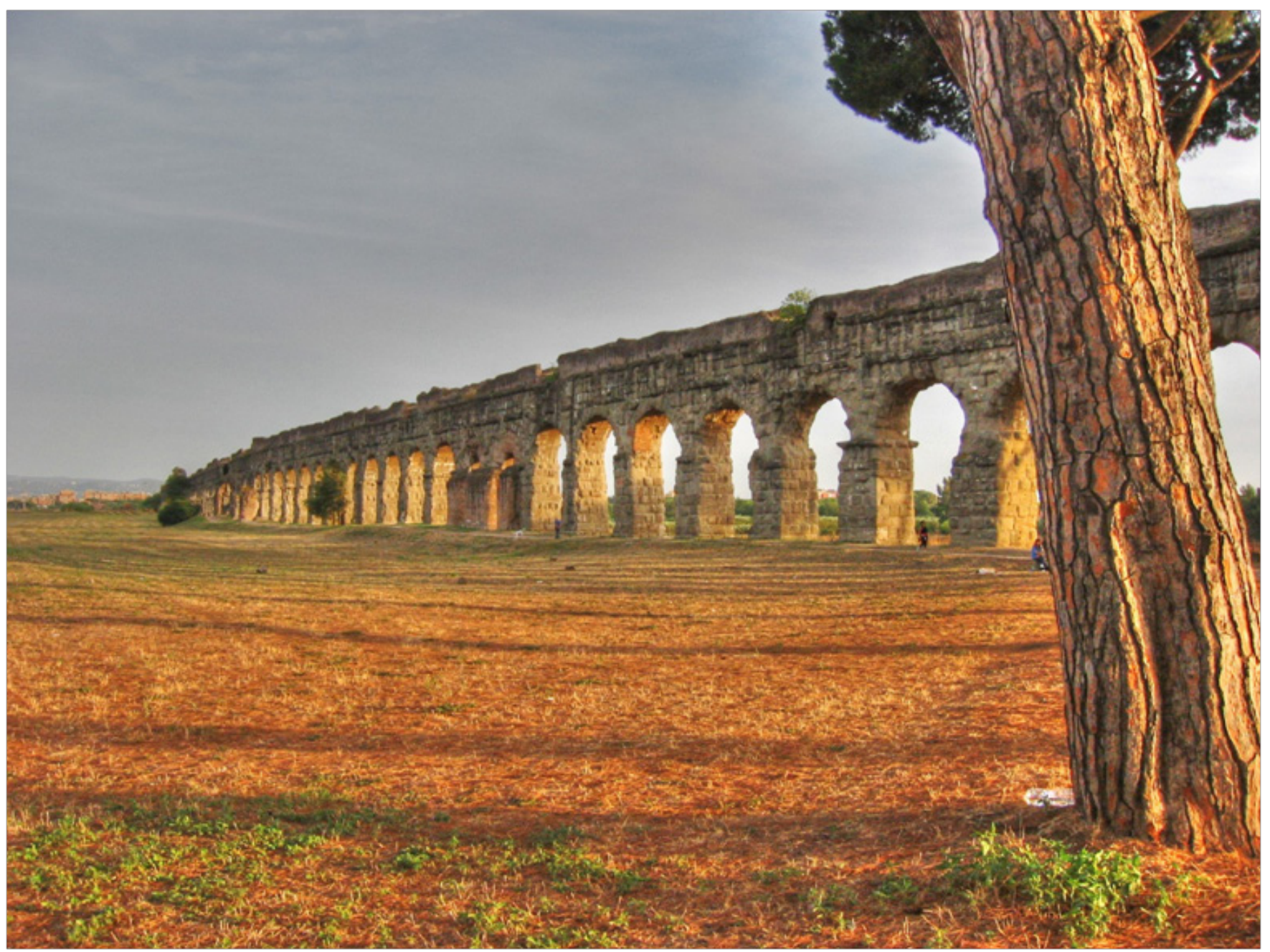

Figure 23 Roman aqueduct (I sec. d.c.). 


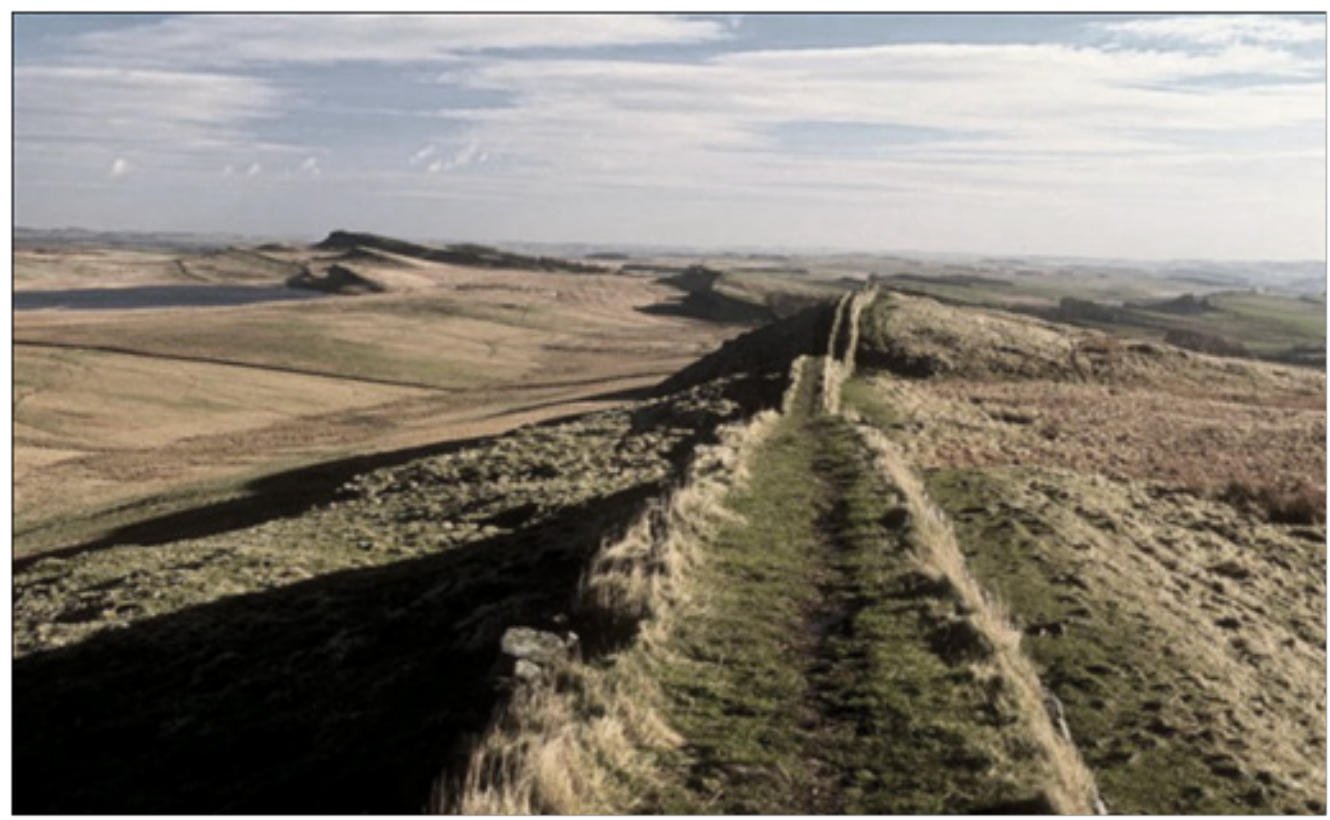

Figure 24 Hadrian's Wall (II sec. d.c.).

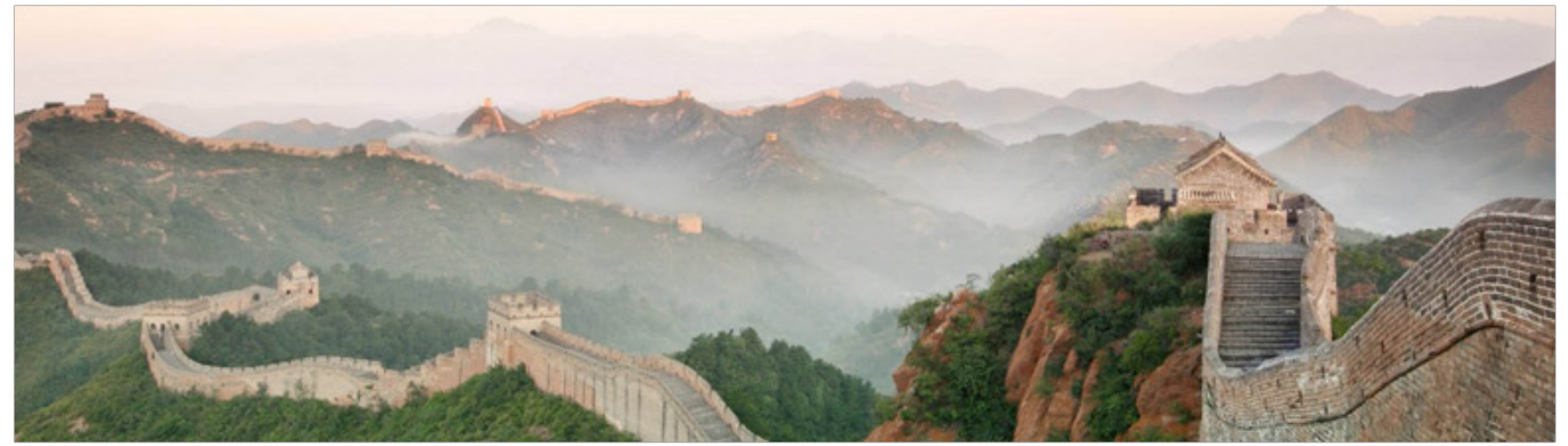

Figure 25 Great Wall of China (Ilsec. a.c.).

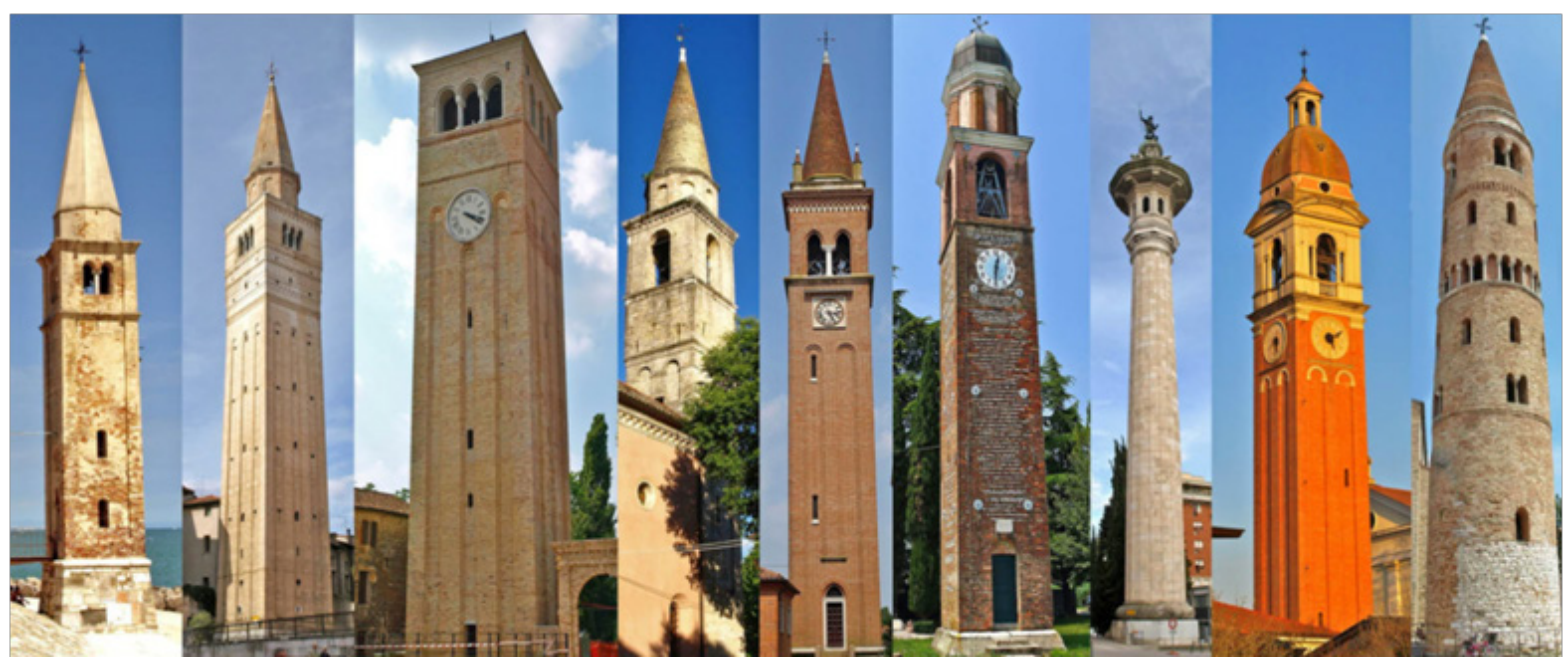

Figure 26 series of historic bell towers of the study area. 


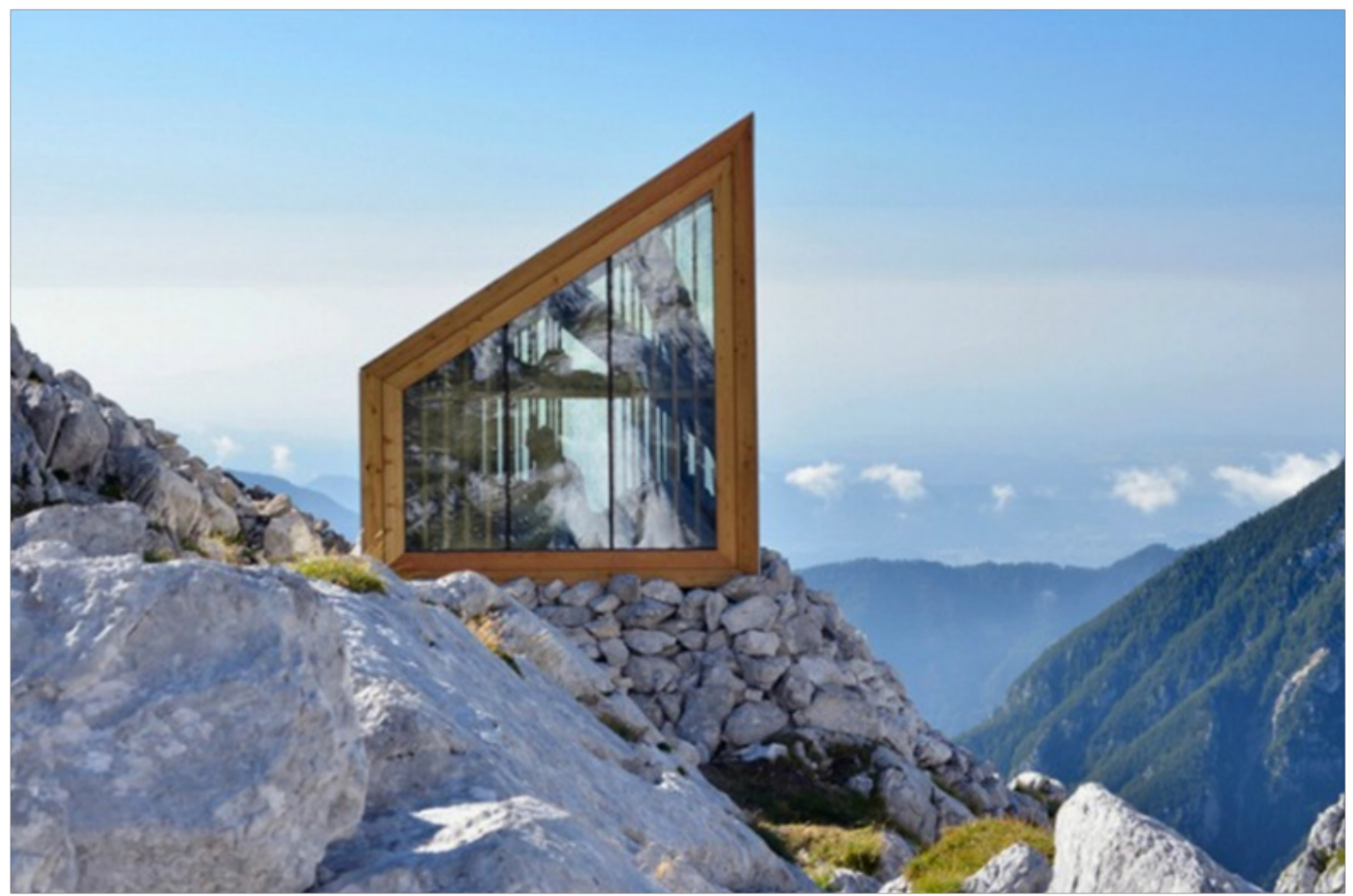

Figure 27 Alpine Refuge, Julian Alps.

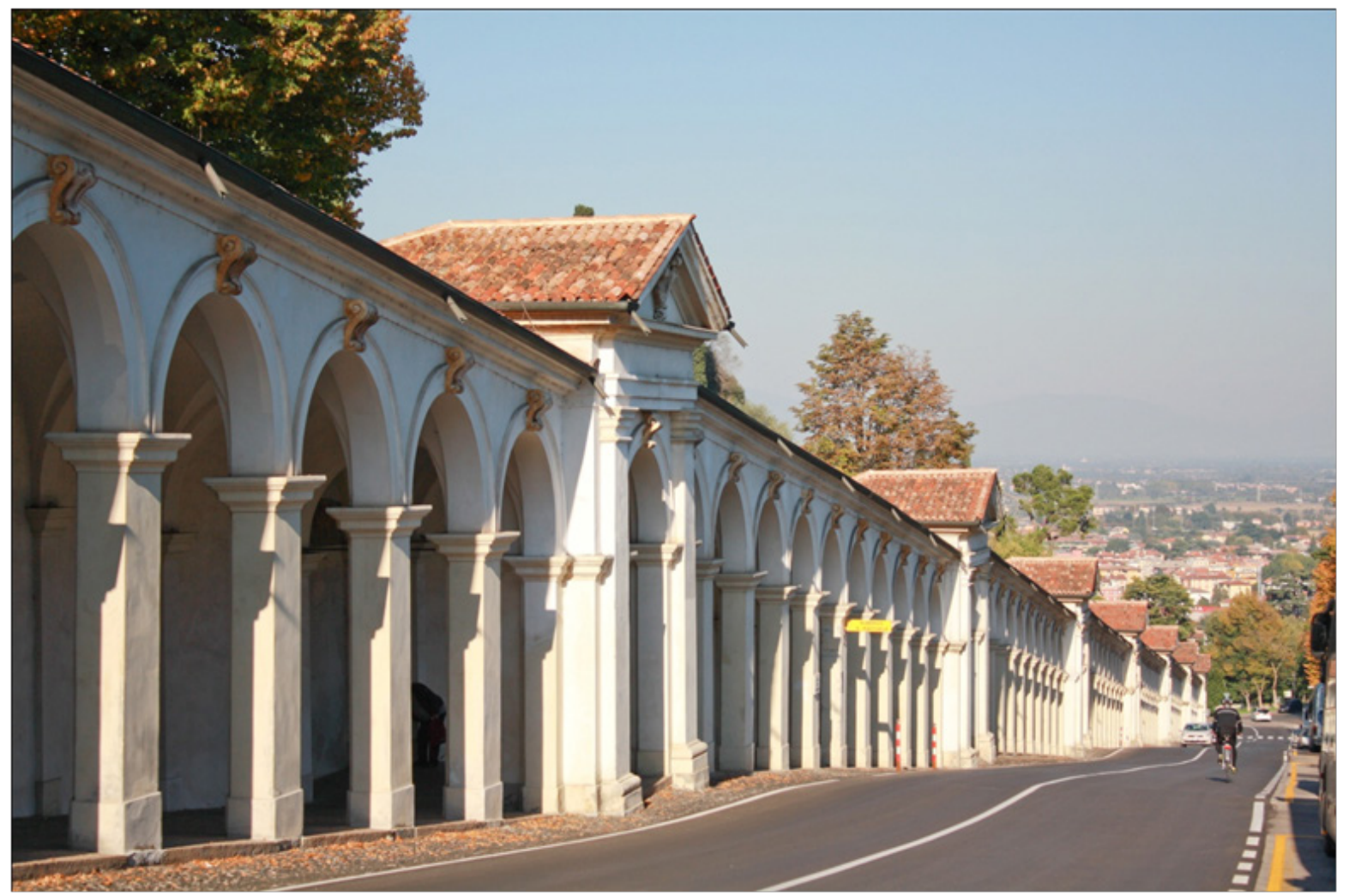

Figure 28 Monte Berico,Vicenza, upper portico on the pilgrimage route (I700). 


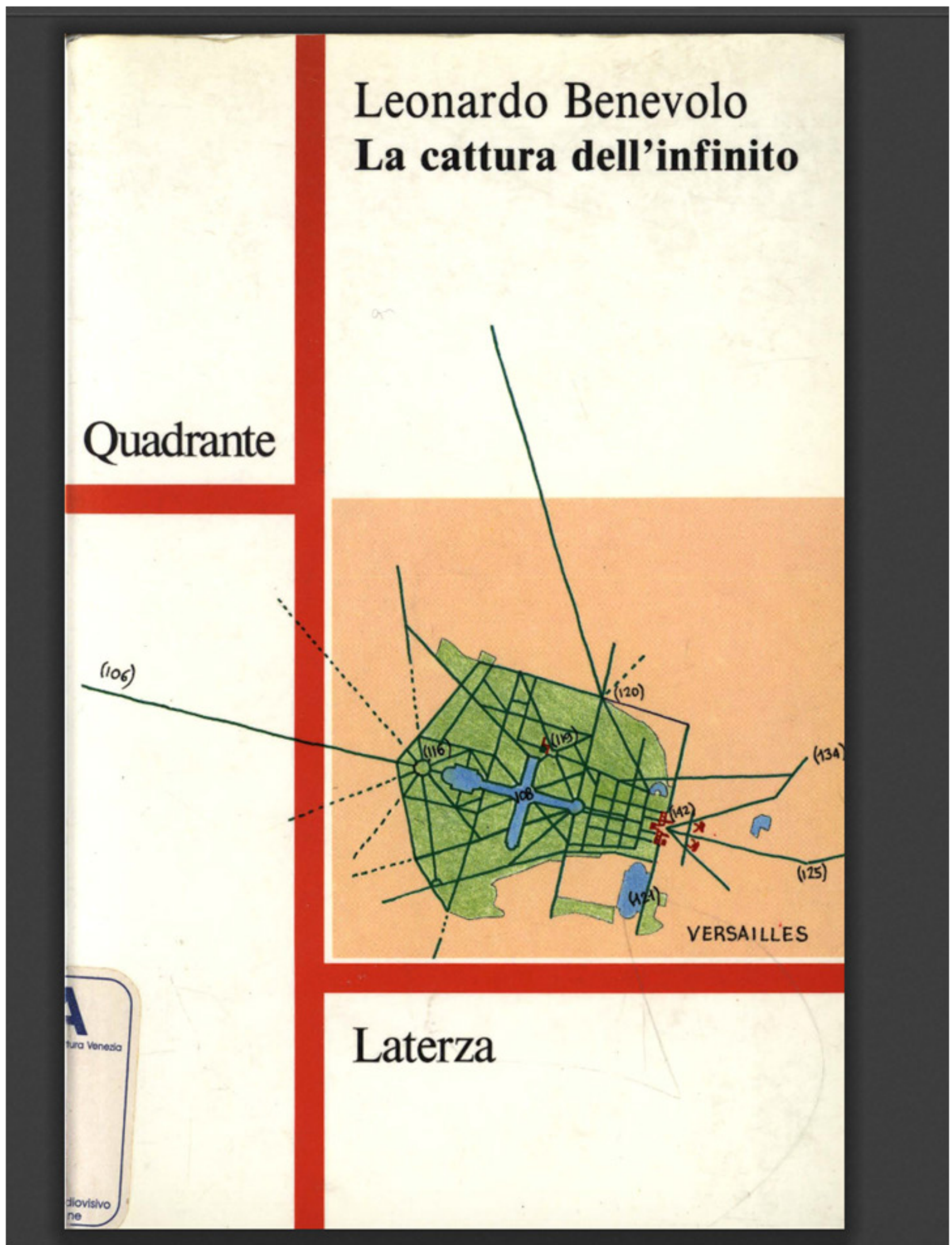

Figure 29 Text cover "La Cattura dell'Infinito" di Leonardo Benvolo. 


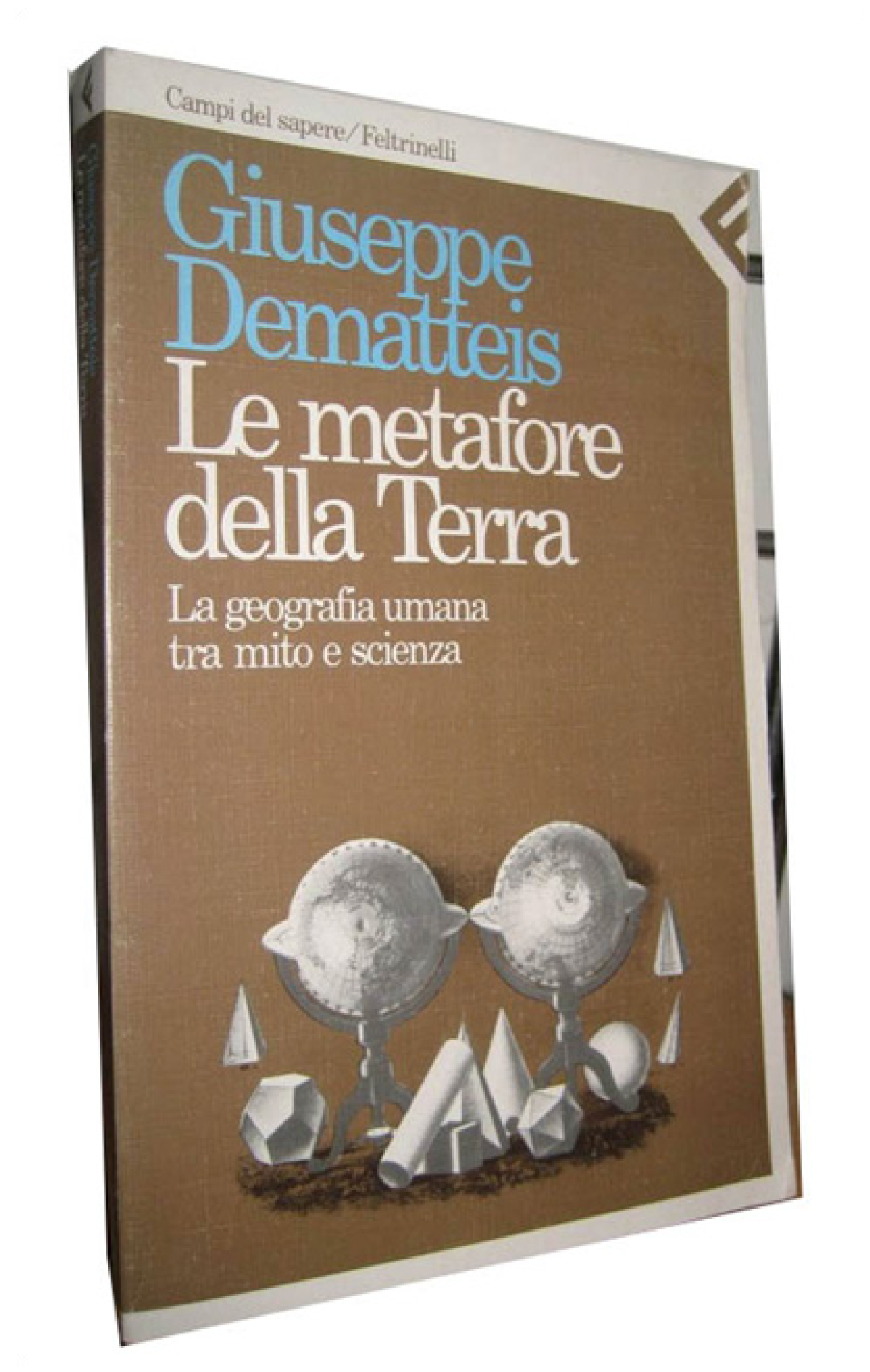

Figure 30 Text cover “ Le metafore della terra. La geografia umana tra mito e scienza” di Giuseppe Dematteis. 

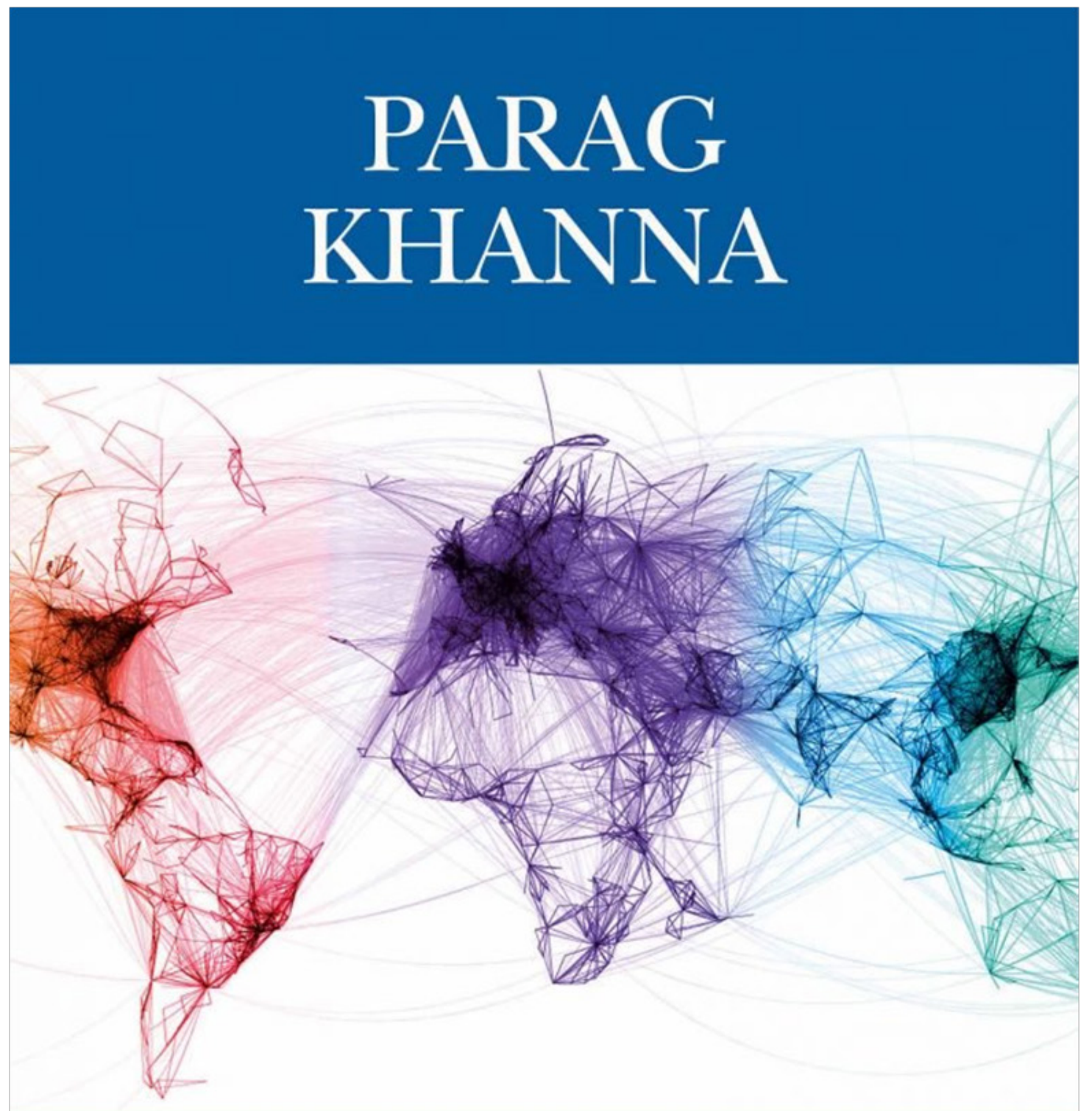

\section{CONNECTOGRAPHY}

Le mappe del futuro ordine mondiale

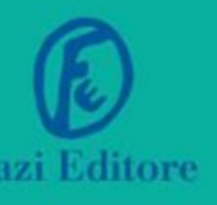

Figure 3I Text cover "Connectography. Le mappe del futuro ordine mondiale" di Parag Khanna. 


\section{Tools and methodology}

\section{Immago limes, visions, fragments, geo_graphies}

The research activity was divided in four phases. The first phase, immago limes, implied an analytical reconstruction of the territory's structure, functioning, throughthe analysis of landscapes, systems (nature, settlements, infrastructures, etc.), fluxes, relations, historical evolution, current ongoing dynamics, obstacles/potential, through data gathering. During the second phase, visions, data were interpreted, summary models were elaborated, extended areas were identified for each segment of the border line, indicators were chosen, ecologies were defined, and thematisation was carried out through "narration". The third phase, frammenti (fragments), implied the development of meta- projects concerning the overall thematisation and the identified obstacles/potential. These meta projects allowed for the focus on specific themes and places for the actual project. During the fourth and last phase, geo_graphies, all information, analytic and project elaborations and experiences were put together to elaborate the final deliverables: eleven ecologies, maps of change, border landscapes, the cross border ring, the city of the border and the new geography of the border (Figure $34 \& 35$ ). ${ }^{20-23}$

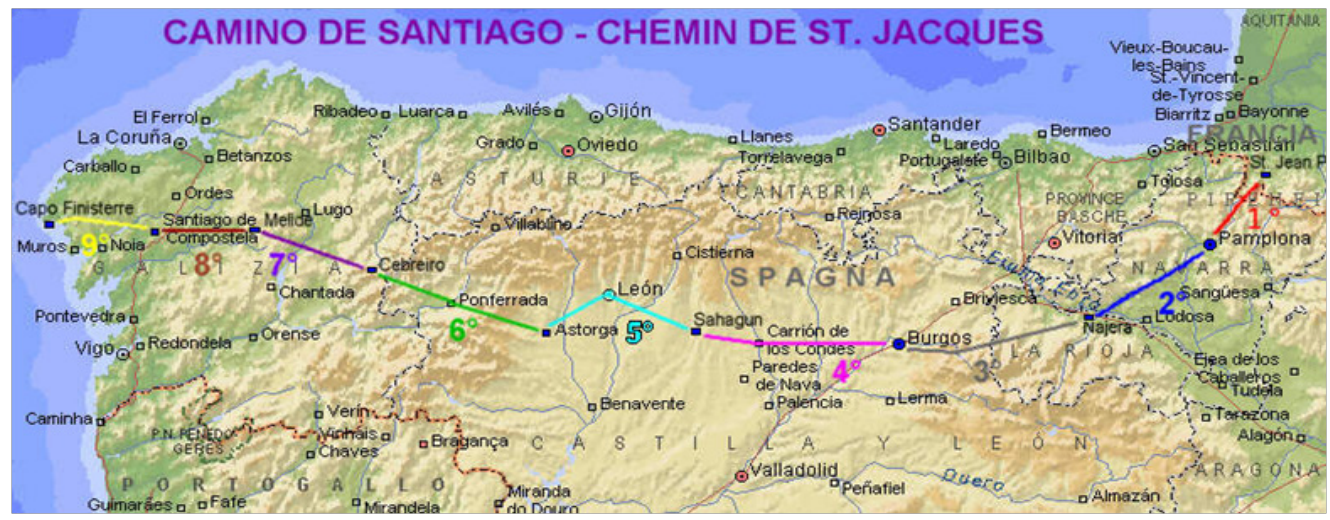

Figure 32 Map of the Camino de Santiago.

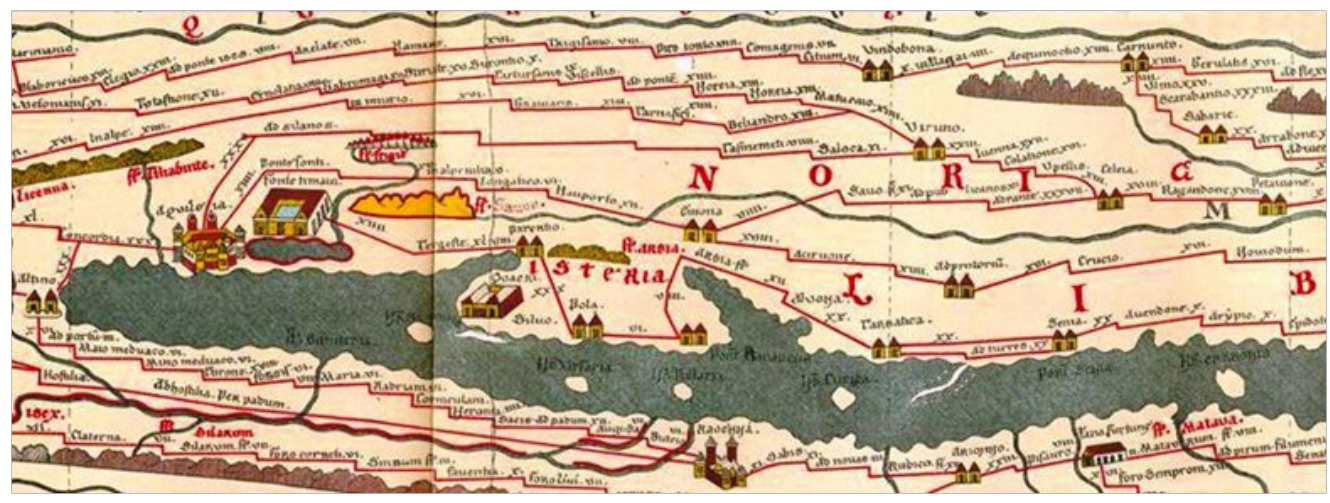

Figure 33 Peutigerian Table of Istria (XII- XIII sec.).

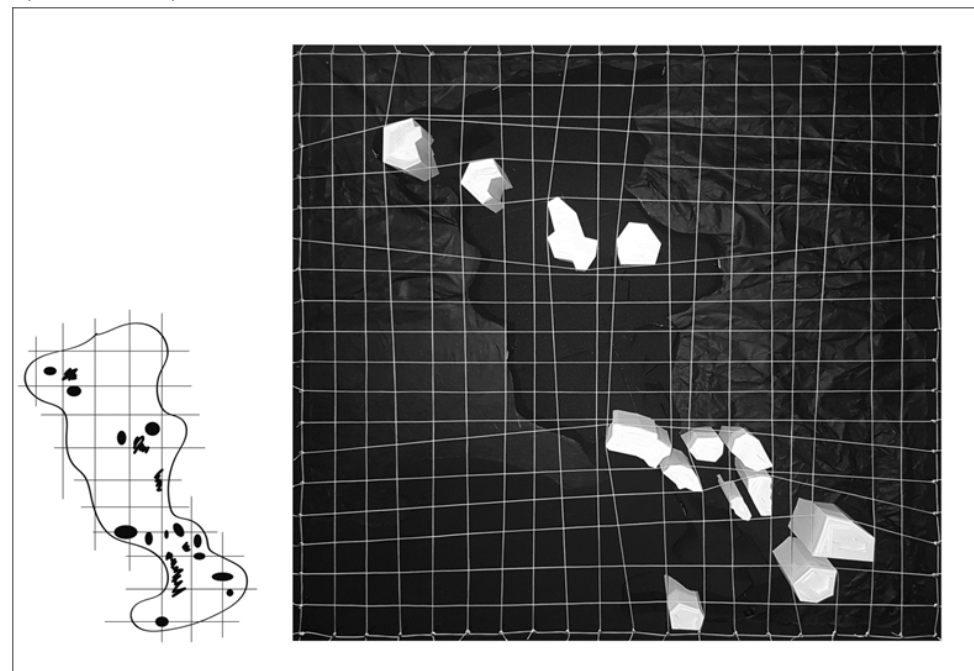

Figure 34 Development of the research team, students Valentina Devescovi, Michela Contin, Lorna Matias. Cave mapping along the border and lithology analysis. 


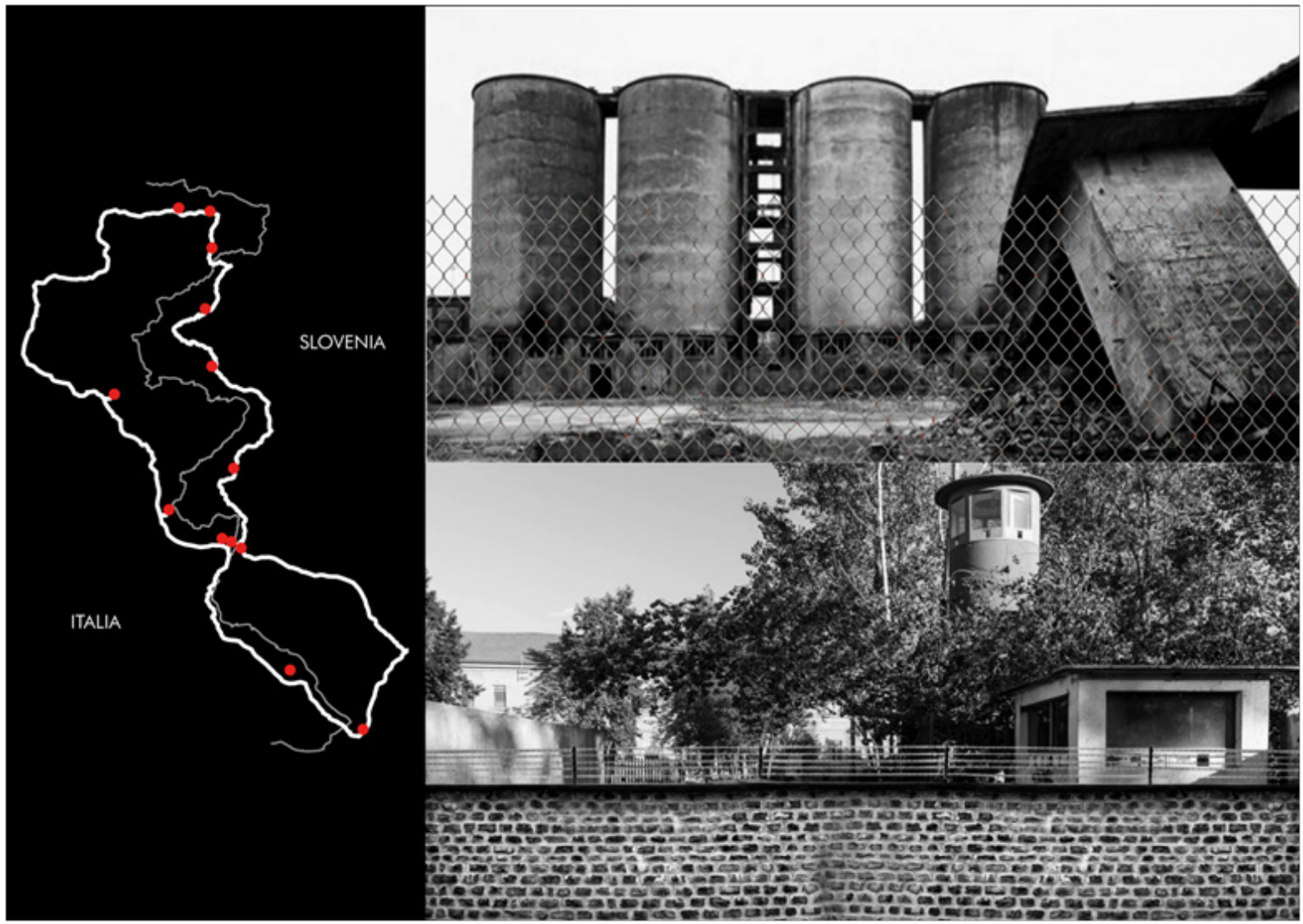

Figure 35 Development of the research team, students Vlad Martinas, Semir Skenderovic. Landscape mapping of terrain vague.

\section{Credits of the research}

Research unit: Integrated Design Laboratory of Architecture and Building, Department of Engineering and Architecture, University of Trieste (IT) with Faculty of Architecture in Ljubljana (SLO);

Research title: New geographies along the border between Italy, Slovenia and Austria Year: 2018-2019;

Coordinator and scientific manager: Giovanni Fraziano (DIA UNITS);

Team of researchers: Adriano Venudo, Claudio Meninno, Luigi Di Dato, Marko Verri, Stefano Simionato (DIA -UNITS), Spela Hudnik (Facoltà Architettura, Università di Lubiana);

Students who have collaborated on the research team: Lorenzo Kratter; Giada Lesizza giada; Angela Bertoni; Virginia Fabbro; Silvia Musini; Arianna Santarsiero; Giorgio Conforto; Eleonora Di Stefano; Debora Paulin; Sofia Artico a; Federica Ferrigno; Lara Slavec; Stela Guni; Giulia Piacente; Giulia Toscano; Vittoria Umani; Vlad Maricel Martinas; Semir Skenderovic; Ivan Bello; Jesku Franklind; Matteo Savron; Elwira Wojcicka; Monica Bidoli; Michela Contin; Valentina Devescovi; Lorna Mattias; Matteo Ros; Milisav Stankovic; Enrico Vidulich, Giacomo Caporale.

\section{Acknowledgments}

i. All the students of the Integrated Design Laboratory of Architecture and Construction a.a.2018-2019: ii. Students: Lorenzo Kratter; Giada Lesizza giada; Angela Bertoni; Virginia Fabbro; Silvia Musini; Arianna Santarsiero; Giorgio CVonforto; Eleonora Di Stefano; Debora Paulin; Sofia Artico a; Federica Ferrigno; Lara Slavec; Stela Guni; Giulia Piacente; Giulia Toscano; Vittoria Umani; Vlad Maricel Martinas; Semir Skenderovic; Ivan Bello; Jesku Franklind; Matteo Savron; Elwira Wojcicka; Monica Bidoli; Michela Contin; Valentina Devescovi; Lorna Mattias; Matteo Ros; Milisav Stankovic; Enrico Vidulich, Giacomo Caporale;

iii. Prof. Giovanni Fraziano, Thomas Bisiani, Claudio Meninno, Luigi Di Dato, Marko Verri, Stefano Simionato, Spela Hudnik (teachers and research team);

iv. Dott.ssa Chiara Bianchizza (translation).

\section{Conflictfs of interest}

The authors declare that there is no conflict of interest.

\section{Funding}

DIA (Engineering and Architecture Department) - UNITS (University of Trieste).

\section{References}

1. Albrecht B, Benevolo L. Confini. A working hypothesis in the International Exposition of the XVII Triennale, Life between things and nature. The project and the environmental challenge, Electa, Milan. 1992. 
2. Benevolo L. History of the city. The contemporary city, Editori Laterza Rome-Bari; 1993.

3. Corboz. The territory as a programming in Casabella. 1985;516.

4. Bufon M. Ethnic and regional development of border areas: the case of Slovenes in Friuli-Venezia Giulia. Slori, Trieste. 1990.

5. Ferrari M, Pasqual E, Wet A. A Moving Border: Alpine Cartographies of Climate Change, Columbia Books on Architecture and the City, with ZKM. Center for Art and Media Karlsruhe. 2019.

6. Basso S. In the Border. Re-readings of the Italian-Slovenian crossborder territory. EUT, Trieste; 2010.

7. Bufon M. For a geography of border areas. The case of the ItalianSlovenian trans-border region in the Gorizia region. In the Italian geographical review. 1994;101:577-605.

8. Dematteis G. The metaphors of the earth: the human geography between myth and science. Milan, Feltrinelli; 1991.

9. Dematteis G, Ferlaino F. The world and places: geographies of identity and change. Institute of Economic and Social Research of Piedmont, Turin; 2003.

10. Zanini P. Significance of the border. The natural, historical and mental limits, Mondadori, Milan; 1997.

11. Dematteis G. Images and interpretations of change in A Clementi. In: Dematteis G, Palermo Pc, Editors. The forms of the Italian territory. Laterza, Bari, 1996;66-79.

12. Jeršič M. The opening of borders as a factor in the development of the Slovenian border regions. Inšt Za geographic Univerze Ljubljana, Ljubljana. 1970.
13. Klemenčič V. Spatial urbanization and ethnic minorities in central Europe. In: De Mauro T, Editor. International Conference on Minorities 10-14 July 1974. Proceedings of the conference, typography Villaggio del Fancillo, Trieste. 1979;59-70.

14. Gabrijelčič P. Internationalization of the border: the place of global initiatives. Development of border region in view of European integration efforts; 2004.

15. Hudnik S. Europe City without borders. 2004.

16. Kačič R. Landscape and rural karst architecture. Ergon, Ronchi dei Legionari. 2001.

17. Zanirato C. Architecture at the limit. The limit of architecture, the architecture of the limit, Alinea, Florence; 1999.

18. Khanna P. Connectography: the maps of the future world order. In: Franco Motta, Editor. Rome, Fazi; 2016.

19. Dinic J. Regionalization of the geographical area of Yugoslavia, in "Geographical Space. Parcourir les collections. 1976;1:49-57.

20. Di Sopra L. The Italian-Yugoslav highway system. Perspective considerations, by the Industrial Association of the province of Gorizia, Gorizia; 1970

21. Greiner L, Dematteis G, Lanza C. Human geography: a visual approach. UTET University, Turin; 2012.

22. Cecla F. What the frontiers are for?, In: Gasparini A, Zago M, Editors Beyond the new walls. The collaborative Europe that comes from the border cities. Franco Angeli, Milan. 1996;298-306.

23. Cecla F, Zanini P. The strictly necessary. Stories and geographies of a limited stretch of sea, Mondadori, Milan; 2004. 